\title{
Potential new biocatalysts for biofuel production: The fungal lipases of Thermomyces lanuginosus and Rhizomucor miehei immobilized on zeolitic supports ion exchanged with transition metals
}

\author{
Adriano de Vasconcellos a , Juliana Bergamasco Laurenti a , Alex Henrique Miller ${ }^{a}$, \\ Danilo Antonio da Silva ${ }^{a}$, Fabio Rogério de Moraes ${ }^{a}$, Donato A.G. Aranda ${ }^{\text {b }}$, José G. Nery ${ }^{\text {a, }}$ \\ a Departamento de Física, Instituto de Biociências, Letras e Ciências Exatas-UNESP - Universidade Estadual Paulista, Campus de São José do Rio Preto, \\ São Paulo, 15054-000, Brazil \\ ${ }^{\mathrm{b}}$ Laboratório Greentec/Escola de Química, Universidade Federal do Rio de Janeiro, CEP 21945-970, Rio de Janeiro, RJ, Brazil
}

\section{A R T I C L E I N F O}

\section{Article history:}

Received 17 January 2015

Received in revised form

30 April 2015

Accepted 3 May 2015

Available online 9 May 2015

\section{Keywords:}

Zeolite-enzyme interaction

Bioinformatic calculations

Biomass

Biofuels

\begin{abstract}
A B S T R A C T
Nanozeolite $\mathrm{NaX}$ ion exchanged with different transition metals $\left(\mathrm{Mn}^{2+}, \mathrm{Cu}^{2+}, \mathrm{Co}^{2+}, \mathrm{Zn}^{2+}, \mathrm{Ni}^{2+}\right)$ was used as a solid support for the immobilization of the lipases of Thermomyces lanuginosus (TLL) and Rhizomucor miehei (RML). The nanozeolite-enzyme complexes were used as heterogeneous catalysts for the transesterification reaction of palm oil to fatty acid ethyl esters (FAEEs). The most relevant results were obtained with the $T$. lanuginosus enzyme immobilized on nanozeolitic supports ion exchanged with $\mathrm{Ni}^{2+}$. Although these zeolitic supports were able to immobilize a relatively small amount of the enzyme (43.7\%) in comparison with the other nanozeolitic supports, the FAEE yields obtained with Nano-X/Ni/ $0.5 \mathrm{M}$-TLL complexes were above $94 \%$. These results revealed an unusual synergistic effect between the T. lanuginosus enzyme and the nickel ion-exchanged nanozeolitic support; this effect was not observed for the complexes prepared with the R. miehei enzyme. Bioinformatics calculations were performed for both enzymes by taking into consideration the crystallographic structures of the enzymes and the zeta potential of the surface of the nanozeolitic supports. By combining calculations of the protein electrostatic potential surface and normal mode analyses in a model, we were able to propose an explanation for the synergistic effect between the lipases and the nanozeolitic supports. The synergistic effect could be explained through an allosteric mechanism describing the interaction between aspartic acid residues 102 and 158 of the T. lanuginosus lipase and the positively charged zeolitic support surface. This interaction results in the stabilization of the opening of the enzyme lid and leaves its catalytic triad permanently exposed to the reaction medium.
\end{abstract}

๑) 2015 Elsevier Inc. All rights reserved.

\section{Introduction}

Biodiesel is a biodegradable and renewable form of energy consisting of alkyl ester fatty acids. It can be produced through the transesterification of vegetable oils or animal fats with short alcohols, such as methanol and ethanol, in the presence of a catalyst $[1-3]$. The transesterification reaction can be catalyzed by homogeneous or heterogeneous acid or by base catalysts and enzymes [4-7]. Lipases are an attractive alternative for biodiesel production due to their high specificity for the transesterification of

\footnotetext{
* Corresponding author. Tel.: +55 173221 2490; fax: +55 1732212247.

E-mail address: nery@ibilce.unesp.br (J.G. Nery).
}

triacylglycerides to fatty acid methyl or ethyl esters (FAME or FAEE) in comparison with the other conventional chemical catalysts employed in industrial biodiesel production. The main advantages of lipases include their ability to utilize all of the mono-, di-, triglycerides and the free fatty acids in the transesterification reaction, the high activity and yields they achieve in non-aqueous media, carrying out the reactions at a low temperature in a short period of time and showing considerable alcohol resistance [8-12]. Despite all of these advantages, some of the main stumbling blocks preventing increased use of enzymes at the industrial scale for biodiesel production are their expensive cost, difficulties in their separation and reuse after the reaction, and the possible deactivation of their active sites by glycerol, which is a subproduct of the transesterification of triacylglycerides into FAEEs [13]. 
One possible way to overcome these obstacles is through immobilization of the enzymes on solid organic or inorganic carriers [14]. Among a plethora of inorganic solid supports available for enzyme immobilization, micrometric zeolites with different framework structures have been systematically studied and explored as carriers [15-19].

Although there have been numerous studies reporting the immobilization of enzymes on micrometric zeolites for different purposes [16-20], the use of nanometric zeolites as a solid supports for enzyme and protein immobilization has steadily attracted the attention of the researchers from different fields. In principle, the reduction of the size of zeolite particles from the micrometer to the nanometer scale can lead to substantial changes in their physicochemical properties, such as increasing their external surface area, allowing better access to and exposure of their active sites, high dispersibility in both aqueous and organic solutions and easy adjustment of their tunable surface properties, especially regarding the surface charge and hydrophilicity/hydrophobicity properties [20]. These properties, together with the typical high adsorption capacity and facile selfassembly character of nanozeolites, create a friendly microenvironment for enzyme and protein immobilization, therefore making of them promising materials for use in proteomics research on the assembly of microchip reactors for effective protein digestion [21], on the construction of glucose biosensors for clinical indication of diabetes [22,23] and on their use as chromatographic carriers in the adsorption and purification of proteins [24].

Although nanozeolites have been studied as solid supports for enzyme and protein immobilization for all of the previously cited applications, a careful survey of the literature shows that the potential of these materials as suitable solid carriers for enzyme immobilization with the aim of biofuel production has not attracted the attention of researchers working in this field. One possible explanation for this lack of interest could be that nanozeolites can not be directly employed in a conventional industrial biodiesel plant without raising practical questions regarding the difficulties of the separation of the products and the biocatalysts. Although this is a legitimate and practical concern from an industrial perspective, from the scientific point of view, the study of the interactions between nanozeolitic supports and fungal lipases could, in principle, shed light on some important questions. For example, a) does the nature of the extra-framework cations of nanozeolites influence the enzymatic activity of the immobilized enzyme on the zeolitic support? b) Does the nanozeolite-enzyme surface interaction induce any synergetic effect on the transesterification reaction of triacylglycerides into FAEEs? c) Do the crystallographic structure and amino acid sequence of the lipases play a role in the final conformation and stabilization of the immobilized enzyme on the zeolitic support, and how will they affect the catalytic sites of the immobilized enzyme? To answer these questions, systematic analyses of nanozeolite synthesis and enzyme immobilization, catalytic analyses and bioinformatic calculations were performed. Nanozeolite NaX was chosen for use in this study because it can be synthesized via conventional hydrothermal methods, without the addition of organic templates or structure-directing agents (SDAs), which makes it a more efficient and economical process $[25,26]$.

Herein, we report the experimental results of our study employing the lipases of Thermomyces lanuginosus (TLL) and Rhizomucor miehei (RML) immobilized on nanosized NaX zeolite (FAU) ion exchanged with $\mathrm{Mn}^{2+}, \mathrm{Cu}^{2+}, \mathrm{Co}^{2+}, \mathrm{Zn}^{2+}, \mathrm{Ni}^{2+}$, in addition to the catalytic performance of these nanozeolite-enzyme complexes in the transesterification reaction of palm oil to FAEEs using ethanol as a solvent.

\section{Experimental section}

\subsection{Materials}

Refined palm oil containing $0.5 \mathrm{wt} \%$ free fatty acid and $1 \%$ water was obtained from Campestre Oil Company (São Bernardo do Campo city, Sao Paulo State, Brazil). Ethanol (99.8\%), 4-nitrophenylpalmitate, gum arabic, Triton X-100, isopropyl alcohol, inorganic salts, the organic basis purchased from Sigma Aldrich and used as received without further purification. The enzymes employed in this work were PALATASE 20,000 L from $R$. miehei lipase and LIPOLASE $100 \mathrm{~L}$ from $T$. lanuginosus lipase and were also purchased from Sigma-Aldrich. These enzymes are purified 1,3-specific lipases (EC 3.1.1.3) and are industrially produced through the submerged fermentation of a genetically modified Aspergillus oryzae [27].

\subsection{Nanozeolite synthesis}

High aluminum content, nanometer-sized NaX zeolite was synthesized through hydrothermal crystallization in a temperaturecontrolled shaker following a procedure reported in the literature $[25,26]$. In a typical synthesis procedure, aluminosilicate gel was prepared by mixing together freshly prepared aluminate and silicate solutions at molar ratio of $5.5 \mathrm{Na}_{2} \mathrm{O}: 1.0 \mathrm{Al}_{2} \mathrm{O}_{3}: 4.0 \mathrm{SiO}_{2}: 190 \mathrm{H}_{2} \mathrm{O}$. An aluminosilicate gel containing $5.34 \mathrm{~g}$ of $\mathrm{NaOH}, 2.42 \mathrm{~g}$ of $\mathrm{NaAlO}_{2}$, $3.43 \mathrm{~g}$ of $\mathrm{SiO}_{2}$, and $50.0 \mathrm{~g}$ of $\mathrm{H}_{2} \mathrm{O}$ was generally used. Fumed silica was chosen as the silicate source and was directly mixed with a freshly prepared aluminate solution at room temperature, then immediately transferred to the temperature-controlled shaker. Hydrothermal crystallization was performed for 2 days at $60{ }^{\circ} \mathrm{C}$, with a shaker rotation rate of $250 \mathrm{rpm}$. The powder product was recovered via centrifugation, washed with DI until achieving a $\mathrm{pH}<8$, and then dried at room temperature for $24 \mathrm{~h}$. This sample was referred to as Nano-X/Na nanozeolite.

\subsection{Ion exchange for the nanozeolitic supports}

Prior to enzyme immobilization, the obtained Nano-X/Na was subjected to ion exchange experiments to replace the sodium cations with metal transition cations. Two different sets of ion exchange experiments were performed. The first was carried out according to the following conditions: $1 \mathrm{~g}$ of Nano-NaX was added to several Teflon lined digestion reactors (Parr Instruments) and to each of these reactors, $30 \mathrm{~mL}$ of solutions $\mathrm{MnSO}_{4}(0.1 \mathrm{M}), \mathrm{CuSO}_{4}(0.1 \mathrm{M})$, $\mathrm{CoSO}_{4}(0.1 \mathrm{M}), \mathrm{ZnSO}_{4}(0.1 \mathrm{M})$, and $\mathrm{NiSO}_{4}(0.1 \mathrm{M})$ was added separately. The ion exchange reactions were maintained at $60^{\circ} \mathrm{C}$ for $16 \mathrm{~h}$, after which the products were centrifuged, and the solid products were washed with distilled water three times and dried at room temperature. These ion-exchanged derivatives were designated Nano-X/Mn/0.1 M, Nano-X/Cu/0.1 M, Nano-X/Co/0.1 M, Nano-X/Zn/ $0.1 \mathrm{M}$ and Nano-X/Ni/0.1 M, respectively. The second ion exchange procedure was similar to the first one, except regarding the concentration of the salt solutions, which was $0.5 \mathrm{M}$, and the temperature and time of the reactions, which were carried out at $60{ }^{\circ} \mathrm{C}$ for $72 \mathrm{~h}$. After the reactions, all of the samples were centrifuged, and the solid samples were washed three times with distilled water and dried at room temperature. These ion-exchanged derivatives were designated Nano-X/Mn/0.5 M, Nano-X/Cu/0.5 M, Nano-X/Co/0.5 M, Nano-X/Zn/0.5 M and Nano-X/Ni/0.5 M.

\subsection{Lipase immobilization on the ion-exchanged nanozeolitic supports}

Lipase (PALATASE 20000 L from $R$. miehei lipase (RML), molecular weight 31,600 Da, pI 3.8) and Lipolase $100 \mathrm{~L}$ (from 
T. lanuginosus lipase (TLL), molecular weight $30 \mathrm{KDa}$, pI 4.4) were immobilized on the nanozeolitic ion-exchanged derivatives with $\mathrm{Mn}^{2+}$ (Nano-X/Mn/0.1 M, Nano-X/Mn/0.5 M), $\mathrm{Cu}^{2+}$ (Nano-X/Cu/ $0.1 \mathrm{M}$, Nano-X/Cu/0.5 M), $\mathrm{Co}^{2+}$ (Nano-X/Co/0.1 M,Nano-X/Co/ $0.5 \mathrm{M}), \mathrm{Zn}^{2+}$ (Nano-X/Zn/0.1 M, Nano-X/Zn/0.5 M) and $\mathrm{Ni}^{2+}$ (Nano$\mathrm{X} / \mathrm{Ni} / 0.1 \mathrm{M}$, Nano-X/Ni/0.5 M). The enzyme immobilization procedure was adapted and optimized from the literature $[28,29]$. The initial concentration of the enzymes and amount of the ionexchanged nanozeolites before immobilization were $2 \mathrm{mg} \mathrm{mL} L^{-1}$ of enzyme for each $200 \mathrm{mg}$ of nanozeolite. The enzymes and nanozeolites were mixed in $5 \mathrm{~mL}$ of $0.3 \mathrm{M}$ phosphate buffer $\mathrm{pH} 7$ and stirred at $600 \mathrm{rpm}$ for $16 \mathrm{~h}$ at room temperature. The nanozeolite-enzyme complexes were separated via centrifugation at $13,400 \mathrm{~g}$, washed twice with de-ionized water, dried at $25{ }^{\circ} \mathrm{C}$ overnight, and then stored at $4{ }^{\circ} \mathrm{C}$ for 2 days before being used in the transesterification reaction. The amount of the immobilized enzymes adsorbed on the zeolitic matrixes, $\mathrm{P}_{\mathrm{g}}(\mathrm{mg} / \mathrm{g})$, was determined according to the method described by Bradford [30], which uses bovine serum albumin as a standard, and were calculated according to Eq. (1):

$P_{g}=\frac{C_{0} V_{0}-C_{f} V_{f}}{w}$

where $C_{0}$ is the initial protein concentration $(\mathrm{mg} / \mathrm{mL}) ; C_{f}$ is the protein concentration in the filtrate $(\mathrm{mg} / \mathrm{mL}) ; V_{0}$ is the initial volume of the lipase solution $(\mathrm{mL}) ; V_{f}$ is the volume of the filtrate $(\mathrm{mL})$; and $w$ is the weight of the zeolitic support used (g) [28].

The nanozeolite-enzyme complexes were named according to the nomenclature of their previous ion-exchanged derivatives and the specific immobilized enzyme. Therefore, the nanozeolite-enzyme complexes derived from $R$. miehei lipase were designated Nano-X/Mn/0.1 M-RML, Nano-X/Mn/0.5 M-RML, Nano$\mathrm{X} / \mathrm{Cu} / 0.1 \mathrm{M}-\mathrm{RML}$, Nano-X/Cu/0.5 M-RML, Nano-X/Co/0.1 M-RML, Nano-X/Co/0.5 M-RML, Nano-X/Zn/0.1 M-RML, Nano-X/Zn/0.5 MRML, Nano-X/Ni/0.1 M-RML and Nano-X/Ni/0.5 M-RML.

The nanozeolite-enzyme complexes derived from T. lanuginosus lipase were designated Nano-X/Mn/0.1 M-TLL, Nano$\mathrm{X} / \mathrm{Mn} / 0.5 \mathrm{M}-\mathrm{TLL}, \mathrm{Nano-X/Cu/0.1} \mathrm{M}-\mathrm{TLL}, \mathrm{Nano}-\mathrm{X} / \mathrm{Cu} / 0.5 \mathrm{M}-\mathrm{TLL}$, Nano-X/Co/0.1 M-TLL, Nano-X/Co/0.5 M-TLL, Nano-X/Zn/0.1 M-TLL, Nano-X/Zn/0.5 M-TLL, Nano-X/Ni/0.1 M-TLL and Nano-X/Ni/0.5 MTLL.

\subsection{Determination of the enzymatic hydrolytic activities of the free and immobilized enzymes}

\subsubsection{Enzymatic hydrolytic activities of the free enzymes measured via the spectrophotometric method}

The enzymatic hydrolytic activities of the free lipases were determined through spectrophotometric analysis according to the method developed by Winkler and Stuckmann [31] and updated by other researchers $[32,33]$. The method consists of measuring the micromoles of 4-nitrophenol released via the hydrolysis of $p$-4nitrophenyl palmitate ( $p$-NPP). The first step of this assay is the preparation of the substrate, which was obtained according to the following method: a stock solution of $p$-NPP $(3 \mathrm{mg} / \mathrm{mL})$ was prepared using an HPLC grade isopropyl alcohol (solution A). Another solution (solution B) composed of gum Arabic (0.5\%) and Triton X$100(2 \%)$ diluted in phosphate buffer ( $\mathrm{pH} 7,0.05 \mathrm{M})$ was prepared, and then $1 \mathrm{~mL}$ of solution A was added to $9 \mathrm{~mL}$ of solution $\mathrm{B}$. This final solution was the substrate. Finally, the enzymatic hydrolytic activities of the free enzymes were measured according to the following procedure: $100 \mu \mathrm{L}$ of free enzyme diluted in phosphate buffer was added to $900 \mu \mathrm{L}$ of the substrate solution, and the mixture was then incubated for $1 \mathrm{~min}$ at $37^{\circ} \mathrm{C}$. The quantity of 4- nitrophenol released was determined photometrically (410 nm), and the assays were performed in triplicate. One unit of lipase activity was defined as the amount of enzyme required to obtain $1 \mu \mathrm{mol}$ of 4-nitrophenol released from 4-NPP per minute under the assay conditions. The enzymatic hydrolytic activities of the free enzymes, $U$, were calculated according to Eq. (2).

$U=\left(\left\{\frac{A b s^{*} V_{t}}{\varepsilon^{*} V_{e} * T}\right\} * 10^{3}\right) * D$

$\mathrm{U}=$ Unit of enzyme activity expressed as $\mathrm{U} / \mathrm{mL}$, where one unit of activity is defined as the release of $1 \mu \mathrm{mol}$ p-nitrophenol from $\mathrm{p}-\mathrm{NPP} / \mathrm{mL}$ min under the assay conditions;

Abs = Absorbance of the sample at $410 \mathrm{~nm}$;

$\mathrm{V}_{\mathrm{t}}=$ Total volume of the reaction $(\mathrm{mL})$;

$\mathrm{V}_{\mathrm{e}}=$ Volume of the enzyme solution $(\mathrm{mL})$;

$\varepsilon=$ Coefficient of molar extinction $\left(\mathrm{L} \mathrm{mol}^{-1} \mathrm{~cm}^{-1}\right)$;

$\mathrm{T}=$ Incubation time;

$10^{3}=$ Factor correction for the coefficient $(\varepsilon)$;

$\mathrm{D}=$ Sample dilution, if necessary.

\subsubsection{Enzymatic hydrolytic activities of the immobilized enzymes measured via the titrimetric method}

The enzymatic hydrolytic activities of the nanozeolite-enzyme complexes were measured using the titrimetric method following the experimental procedures described in the ACS Specifications [34] and in the Sigma Standard tests employed in the enzymatic assay for lipase (EC 3.1.1.3), with slight modifications [35-37]. In a typical assay, a mixture composed of $20 \mathrm{mM}$ of phosphate buffer, gum arabic ( $1 \% \mathrm{w} / \mathrm{v})$ and the substrate (soybean oil) $1: 1(\mathrm{v} / \mathrm{v})$ was brought up to a total volume of $10 \mathrm{~mL}$. The reaction was thoroughly mixed and equilibrated at $37{ }^{\circ} \mathrm{C}$, and $30 \mathrm{mg}$ of a nanozeolite-enzyme complex was added after being incubated at the same temperature. The reaction was left at $37^{\circ} \mathrm{C}$ for exactly $30 \mathrm{~min}$ and quenched by adding $3 \mathrm{~mL}$ of $95 \%$ ethanol, then cooled to minus $4{ }^{\circ} \mathrm{C}$ using an ice/ethanol bath. The solution was centrifuged at $13,400 \mathrm{~g}$ to separate the solids and the fatty acids in the supernatants released from the oil substrate during enzymatic hydrolysis. The fatty acids were immediately titrated to neutralization with $50 \mathrm{mM} \mathrm{NaOH}$ in the presence of thymolphthalein as an indicator. Blank solutions for each of the nanozeolitic supports were prepared following the same experimental procedure, but in the absence of the enzymes.

One unit of lipase activity was expressed as micro equivalents of fatty acid released from triglyceride in $1 \mathrm{~h}$ at $37^{\circ} \mathrm{C}$ and calculated according to Eq. (3).

Units $/$ mg solid $=\frac{(\mathrm{NaOH})(\text { Molarity of } \mathrm{NaOH})(1000)(2)}{\text { mg solid }}$

$\mathrm{NaOH}=$ Volume (in milliliters)

$1000=$ Conversion factor from milli equivalents to micro equivalents

2 = Time conversion factor from $30 \mathrm{~min}$ to $1 \mathrm{~h}$ (Unit Definition) mg solid = Mass (in milligrams) of the nanozeolite-enzyme complexes used.

\subsection{Physicochemical characterization of the nanozeolites and nanozeolite-enzyme complexes}

The materials prepared in the previous sections were characterized via XRD, SEM. XRD data were collected with a Rigaku MiniFlex II (Tokyo, Japan) on a rotating anode source with a flat- 
plate Bragg-Brentano geometry, operating with $\mathrm{Cu} \mathrm{K} \alpha$ radiation (wavelength $=1.5418 \AA$ ) at $40 \mathrm{kV}$ and $40 \mathrm{~mA}$, and equipped with a graphite monochromator. The powder diffraction patterns were recorded in the range of $2 \alpha=3-50^{\circ}$ with a goniometer at a rate of $2^{\circ}(2 \theta) \mathrm{min}^{-1}$. SEM images were recorded using a XL30 FEG instrument, and before the analysis, a thin coating of gold was deposited onto the samples. Nitrogen isotherms at T $77 \mathrm{~K}$ were determined using a volumetric adsorption apparatus (Micromerities, ASAP 2010). Prior to the measurements, all samples were degassed at $200{ }^{\circ} \mathrm{C}$ until the pressure was less than $1 \mathrm{~Pa}$ and the degassing rate was less than $1 \mathrm{~Pa} \mathrm{~min}^{-1}$. The surface area was estimated using the BET method, and the pore distribution was determined using a cylindrical pore geometry model. Elemental chemical analyses of $\mathrm{Si}, \mathrm{Al}, \mathrm{Na}, \mathrm{Mn}, \mathrm{Cu}, \mathrm{Co}, \mathrm{Zn}$, and $\mathrm{Ni}$ in the nanozeolitic supports were performed via inductively coupled plasma atomic emission spectroscopy (ICP-AES, Chemical Analysis Labs-Sao Paulo University Facilities-USP). HR-TEM data were obtained from powdered glasses suspended in ethanol and deposited on grids using an FEI Model Tecnai G2 F20 (200 kV) microscope equipped with a field emission gun. AFM experiments were performed at the Brazilian National Laboratory of Nanotecnology (LNNano-Campinas). The data were collected using a Dimension 3000 scanning probe microscope (SPM) equipped with a NanoScopeIIla SMP controller (digital Instruments Inc.). Tapping mode AFM images were acquired in ambient air using TESP tapping mode etched silicon probes. The XPS analysis was carried out at a pressure of less than $5 \times 10^{-7}$ Pa using a commercial spectrometer (UNISPECS UHV System). The Mg K $\alpha$ line was used (hu=1253.6 eV) and the analyzer pass energy was set to $10 \mathrm{eV}$. The inelastic background of the C 1s, O 1s, Si 1p, Al 2p, S 2p and Ni 2p3/2 electron core-level spectra was subtracted via Shirley's method. The composition (at.\%) of the near-surface region was determined with an accuracy of $\pm 10 \%$ from the ratio of the relative peak areas corrected by Scofield's sensitivity factors for the corresponding elements. The binding energy scales of the spectra were corrected using the $C 1 \mathrm{~s}$ hydrocarbon component of the fixed value of $285.0 \mathrm{eV}$. The spectra were fitted without placing constraints using multiple Voigt profiles. The width at half maximum (FWHM) varied between 1.2 and $2.1 \mathrm{eV}$, and the accuracy of the peak positions was $\pm 0.1 \mathrm{eV}$.

\subsection{Syntheses of FAEEs}

The transesterification reactions of palm oil to biodiesel were performed with three different catalyst groups: free enzymes; pure nanozeolites (Nano-X/Cu/0.5 M, Nano-X/Mn/0.5 M, Nano-X/Co/ $0.5 \mathrm{M}, \mathrm{Nano}-\mathrm{X} / \mathrm{Zn} / 0.5 \mathrm{M}$ and Nano-X/Ni/0.5 M); and the nanozeolite-enzyme complexes derived from the $R$. miehei enzyme (Nano-X/Mn/0.5 M-RML, Nano-X/Cu/0.5 M-RML, Nano-X/Co/ 0.5 M-RML, Nano-X/Zn/0.5 M-RML, Nano-X/Ni/0.5 M-RML) and the nanozeolite-enzyme complexes derived from the T. lanuginosus enzyme (Nano-X/Mn/0.5 M-TLL, Nano-X/Cu/0.5 M-TLL, Nano-X/Co/ 0.5 M-TLL, Nano-X/Zn/0.5 M-TLL, Nano-X/Ni/0.5 M-TLL).

Several experiments were performed to determine appropriate reactions conditions to allow comparison between the three catalyst groups.

The catalytic enzymatic activities of the $R$. miehei and T. lanuginosus lipases immobilized on the zeolitic supports obtained from the ion exchange experiments with $0.1 \mathrm{M}$ solutions were quite low (see Section 2.5.2), and consequently, these nanozeolite-enzyme complexes were not tested in the transesterification reactions.

Transesterification reactions catalyzed by the free enzymes and the nanozeolite-enzyme complexes were performed with an oil: ethanol ratio of $1: 4$ at $40{ }^{\circ} \mathrm{C}$. The total amount of ethanol was equally divided and added in a stepwise fashion to the reaction over four different time intervals (time: $0,3,6$ and $24 \mathrm{~h}$ ) in order to preclude the inactivation of the catalysts. After a reaction time of $48 \mathrm{~h}$, the product (biodiesel) and sub-product (glycerol) were separated via centrifugation at $13,400 \mathrm{~g}$. The progress of the transesterification reactions was followed via thin layer chromatography (TLC) according to a procedure described by Yang et al. [38]. At predetermined time intervals, a small volume $(100 \mu \mathrm{L})$ of the reaction mixture was collected and mixed with $500 \mu \mathrm{L}$ of hexane for $2 \mathrm{~min}$. After separation via centrifugation, $3 \mu \mathrm{L}$ of the upper layer was applied to a silica gel plate. A solution of hexane/ ethyl acetate/acetic acid (90:10:1) was used as a developing solvent, and iodine was used as a color reagent.

\subsection{Gas chromatography}

Chromatographic analyses were performed with a PerkinElmer Clarus580 Gas Chromatograph equipped with a flame ionization detector (GC-FID). The chromatograph was configured with an injector in split mode coupled to an auto-sampler for liquid samples. The chromatographic conditions employed in the quantification of fatty acid esters according to EN 14103 were as follows: sample injection volume $=1 \mathrm{~mL}$, split $=1: 20$, injector and detector temperature $=250{ }^{\circ} \mathrm{C}$, isothermal oven temperature $=210{ }^{\circ} \mathrm{C}$, pressure of helium carrier gas $=83 \mathrm{kPa}$ due to using the "split" mode and adjustment to clearly visualize the peak of the ethyl standard C24:1. The capillary column employed was a Restek-Carbowax, $30 \mathrm{~m}$ long, with a $0.25 \mathrm{~mm}$ internal diameter and a $0.25 \mathrm{~mm}$ stationary phase thickness.

\subsubsection{Quantification of ester contents}

The quantification of FAEE content was performed in triplicate according to EN 14103. The quantification of fatty ethyl esters in the samples was performed as follows: $20 \mathrm{mg} / \mathrm{mL}$ stock solutions of the ethyl myristate (C14:0) and ethyl nervonate (C24:1) standards were prepared, whereas the ethylic nonadecanoate standard was prepared in a $10 \mathrm{mg} / \mathrm{mL}$ stock solution. The ethyl ester standards C14:0 and $\mathrm{C} 24: 1$ were used to identify the range of integration. In addition, an ethylic ester (C19:0) was used as the internal standard (IS). The ester contents were obtained by integrating the peak areas ranging from $\mathrm{C} 14: 0$ to $\mathrm{C} 24: 0$ and subtracting the nonadecanoate area, as shown in Eq. (4):

$C=\frac{\sum A-A_{I S}}{A_{I S}} \times \frac{C_{I S}-V_{I S}}{m} \times 100 \%$

where:

$$
\begin{aligned}
& \sum \mathrm{A}=\text { sum of the areas of all peaks ranging from } \mathrm{C} 14: 0 \text { and } \\
& \mathrm{C} 24: 0 \\
& \mathrm{AIS}=\mathrm{C} 19: 0 \text { IS area } \\
& \mathrm{CIS}=\text { concentration }(\mathrm{mg} / \mathrm{mL}) \text { of the } \mathrm{C} 19: 0 \text { solution } \\
& \mathrm{VIS}=\text { volume of the } \mathrm{C} 19: 0 \mathrm{solution} \text { added to sample } \\
& \mathrm{m}=\text { mass of the sample }(\mathrm{mg}) .
\end{aligned}
$$

\subsection{Electrostatic potential surface}

Electrostatics area major component of protein-zeolite interactions. Therefore, it is necessary to check for charge complementarities that show evidence of possible binding sites. To calculate the electrostatic potential surface of the T. lanuginosus and $R$. miehei lipases, the PDB2PQR server 1.8 [39] was used to obtain their atomic charges and radii, as shown in the Amber force field [40]. APBS software (Adaptive Poisson-Boltzmann Solver, version 1.3) [41] was employed to solve the Poisson-Boltzmann equation based on the PQR file previously generated. The proteins were 
centered in a cubic box, and the single Debye Huckel boundary condition was applied. Positive and negative mobile ions were placed in a concentration of $10.0 \mathrm{mM}$. The protein and solvent dielectric constants were set to 2.00 and 78.54 , respectively. A radius probe of $1.4 \AA$ and temperature of $298.15 \mathrm{~K}$ were chosen. The results were loaded into PyMol Version 1.5.0.4 (Schrödinger, LLC.) for visualization purposes [42].

\subsubsection{Lipase normal mode analysis}

Due to the lack of an unified force field for describing the total protein-zeolite complex interaction, it was decided to carry out the simulations using the protein dynamics and actions related to the lid opening of the enzyme catalytic sites. Normal mode analysis has been successfully applied to gain insight into the dynamics of proteins and their functions [43]. Lipase activation is related to enzyme lid opening, which, in turn, exposes the catalytic triad Ser146, Asp-201 and His-256 to the substrate.

In this study, the intrinsic dynamics of proteins were studied by associating spring-like constants with each chemical bond in the protein, using the parameters from the Amber force field.

To this end, normal mode analysis using the vibrate command in the TINKER Molecular Modeling package was carried out [44]. Prior to normal mode analysis, minimization protein structure energy was performed using the minimize module of TINKER software. The energy convergence criterion was set to $0.1 \mathrm{kcal} / \mathrm{mol}$. The first 15 normal modes representing the lowest vibration frequencies of the protein structure were selected for further analyses.

\section{Results and discussion}

Analyses of the XRD patterns (Figs. 1-3) of the synthesized Nano-X/Na sample and its ion-exchanged derivatives obtained under different ion exchange conditions revealed how sensitive and flexible the Nano-X/Na framework is to the cation dominant medium, ion concentration and temperature condition parameters.

In the case of the ion-exchanged derivatives Nano-X/Mn/0.1 M, Nano-X/Cu/0.1 M, Nano-X/Co/0.1 M, Nano-X/Zn/0.1 M and Nano-X/ $\mathrm{Ni} / 0.1 \mathrm{M}$, most of the original Bragg reflections originally present in the synthesized Nano-X/Na remained (Fig. 1). On the other hand, the ion-exchanged derivates Nano-X/Cu/0.5 M, Nano-X/Co/0.5 M, Nano-X/Zn/0.5 M and Nano-X/Ni/0.5 M underwent drastic changes in their crystallographic structures (Fig. 2). The only exception was observed for the Nano-X/Mn/0.5 M ion-exchanged derivates, which retained the original Bragg reflections originally present in Nano-X/ $\mathrm{Na}$. In addition to the absence of the original Bragg reflections, it was observed that the Nano-X/Co/0.5 M, Nano-X/Zn/0.5 M and Nano-X/Ni/0.5 $\mathrm{M}$ ion-exchanged derivates showed broad, lowintensity Bragg reflections, providing evidence of the small size of their crystals, and SEM data confirmed this observation (Fig. 4). The chemical compositions of the obtained Nano-X/Na and the ionexchanged derivatives Nano-X/Mn/0.5 $\mathrm{M}$, Nano-X/Cu/0.5 $\mathrm{M}$, Nano-X/Co/0.5 M, Nano-X/Zn/0.5 M and Nano-X/Ni/0.5 M were determined via ICP-AES and are displayed in Table 1 . It is evident from the data from the ion exchange experiments for the system under investigation that some cations can promote different degrees of amorphization of the synthesized Nano-X, whereas other cations can promote the crystallization of new structures. In the case of Nano-X/Mn/0.5 M, Nano-X/Co/0.5 M, and Nano-X/Ni/0.5 M, the degree of amorphization differed from one sample to another (Fig. 2). Nevertheless, some of the original Bragg reflections typical of the Na-X zeolite were retained. The same findings were not obtained for Nano-X/Zn/0.5 M, whose degree of amorphization was more severe compared with the other ion-exchanged derivatives (Fig. 2). Attempts to identify this material using the x-ray powder diffraction database JCPDS were unsuccessful. This loss of

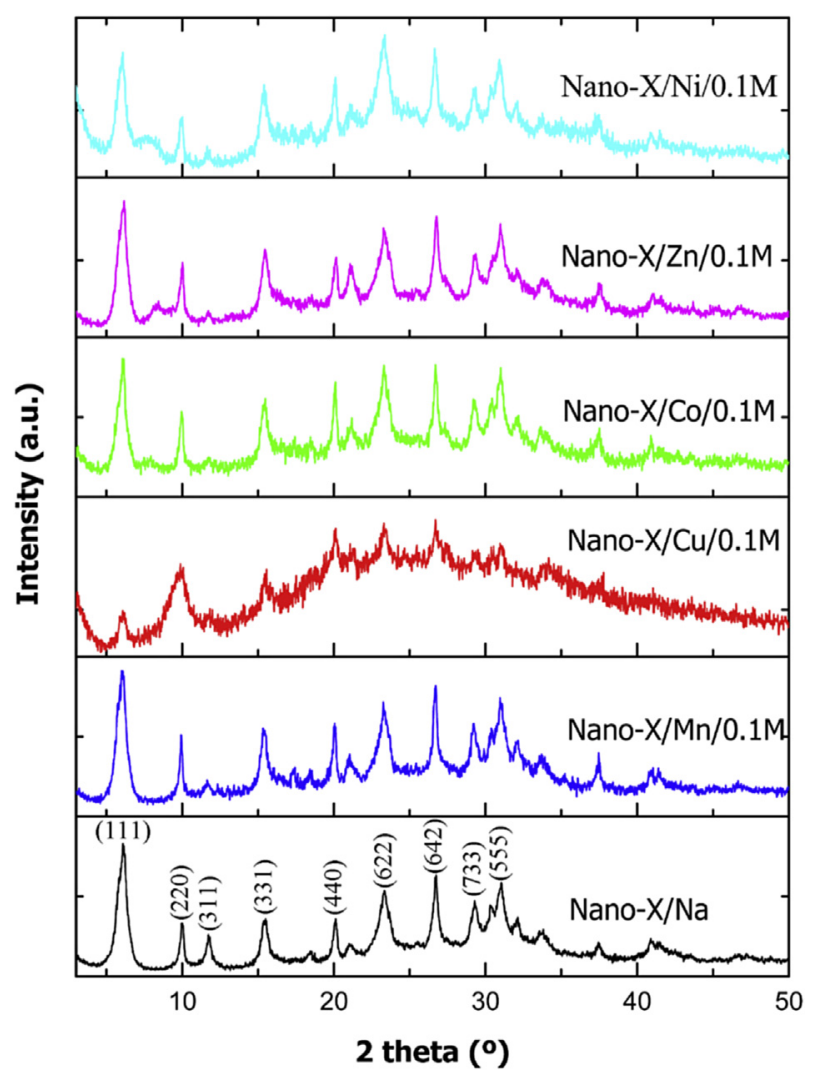

Fig. 1. XRD patterns of the Nano-X (Na) ion exchanged with $\mathrm{Mn}, \mathrm{Cu}, \mathrm{Co}, \mathrm{Zn}, \mathrm{Ni}$ at $0.1 \mathrm{M}$ concentration $/ 16 \mathrm{~h}$.

crystallinity can be attributed to two causes: (i) a lower Si/Al ratio of the zeolite framework, which in turn, causes lower chemical stability $(1.0<\mathrm{Si} / \mathrm{Al}<1.5$ for zeolite $\mathrm{X}$ ) (the $\mathrm{Si} / \mathrm{Al}$ determined through ICP-AES for the obtained Nano-X was calculated to be 1.59 , see Table 1); and (ii) the $\mathrm{pH}$ of the $\mathrm{Cu}^{2+}(\mathrm{pH} \sim 4.3), \mathrm{Mn}^{2+}$ ( $\left.\mathrm{pH} \sim 6.2\right), \mathrm{Co}^{2+}$ ( $\mathrm{pH} \sim 4.6), \mathrm{Zn}^{2+}(\mathrm{pH} \sim 6.1)$ and $\mathrm{Ni}^{2+}(\mathrm{pH} \sim 6.7)$ ion exchange solution media likely caused amorphization of the zeolitic framework [45-49].

On the other hand, it is worth noting that the Nano-X/Na ion exchanged with $\mathrm{Cu}^{2+}$ shifted from a Faujasite topology (FAU) to a Gismondine topology (GIS) [50], showing that under these ion exchange or synthesis conditions, $\mathrm{Cu}^{2+}$ can act as a structuredirecting agent, as it was able to direct the transformation of Nano-X/Na (FAU) into micrometric cupric enriched gismondine zeolite (GIS) (Fig. 2). The role of organic cations that can act as SDAs has been well discussed in the literature through excellent reviews [51-55]. However, the role of inorganic cations acting as promoters of new zeolites structures has not been widely discussed or reported in the literature. Barrer [56] and Flanigen [57] have reported the role of sodium ions $\left(\mathrm{Na}^{+}\right)$in the formation of the several zeolitic subunits, such as double four rings (D4R) and double six rings (D6R), in the syntheses and stabilization of gmelinite and sodalite structures, whereas other species, such as $\mathrm{Rb}^{+}, \mathrm{K}^{+}$, and $\mathrm{Ba}^{2+}$, have been found to be responsible for directing the formation and stabilization of cancrinite. Barrer [51] were also able to prepare synthetic counterparts of the natural zeolites heulandites (HEU), yugawaralite (WG), and harmotone (PHI) using $\mathrm{Sr}^{2+}, \mathrm{Ba}^{2+}$, and $\mathrm{Ca}^{2+}$, respectively, as structure-directing agents. Davis and Lobo [52] proposed the use of different cations, rather than alkali-metal ions, as structure-directing agents in zeolite synthesis, but experimental evidence of the role of $\mathrm{Cu}^{2+}$ acting as a structure-directing 


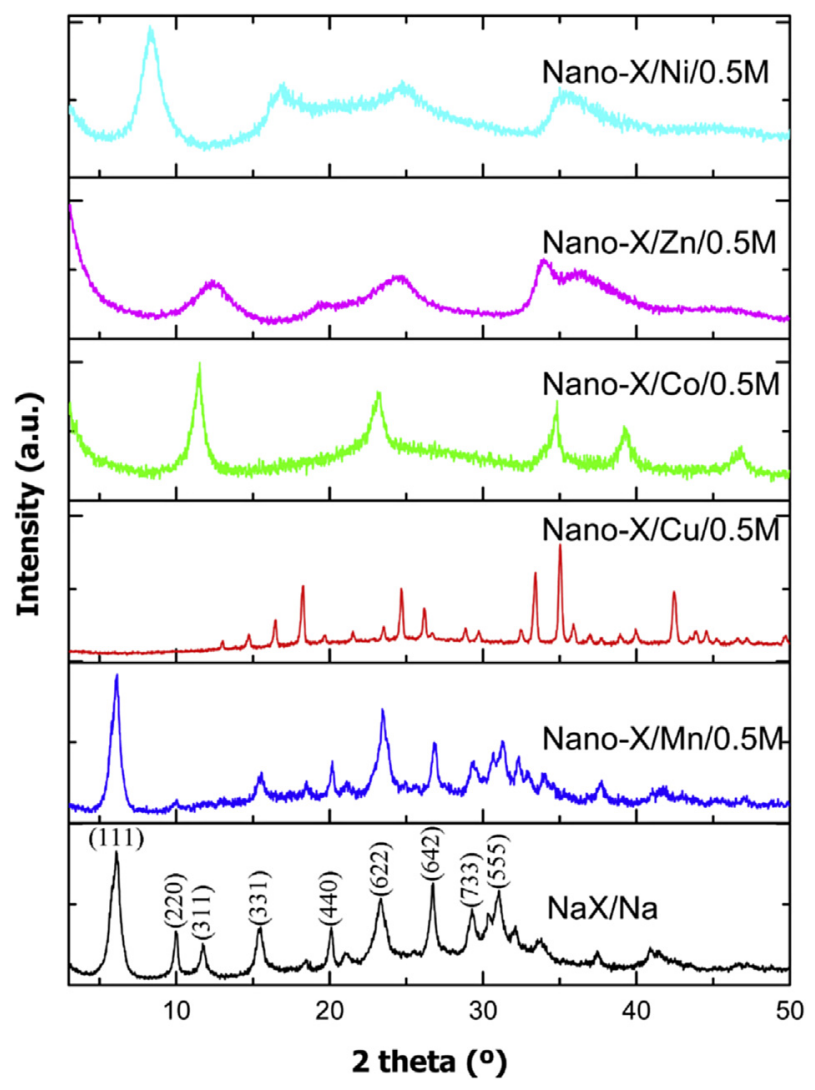

Fig. 2. XRD patterns of the Nano-X (Na) ion exchanged with $\mathrm{Mn}, \mathrm{Cu}, \mathrm{Co}, \mathrm{Zn}, \mathrm{Ni}$ at $0.5 \mathrm{M}$ concentration $/ 72 \mathrm{~h} / 60{ }^{\circ} \mathrm{C}$

agent has not yet been reported in the literature to the best of our knowledge. To gain a better understanding of the role of $\mathrm{Cu}^{2+}$ in this particular system, several experiments with varying reaction times were performed, and the results are shown in Fig. 3. It can be observed that after $16 \mathrm{~h}$, the original crystallographic structure had completely collapsed, and only two diffraction peaks from the original structure remained, located at $2 \Theta=10^{\circ}$ and $35^{\circ}$, respectively (Fig. 3). After $24 \mathrm{~h}$, there were 7 new Bragg reflections, located at $2 \Theta=17^{\circ}, 19^{\circ}, 25^{\circ}, 34^{\circ}, 36^{\circ}$, and $42^{\circ}$, and 48 h later, this structure had evolved into a more crystalline and stable one (Fig. 3). It is important to note that this facility in promoting crystallization from one structure to another was observed only for the cation $\mathrm{Cu}^{2+}$ in this system.

Figs. 4 and 5 show the SEM and TEM data, respectively, collected for the synthesized Nano-X/Na and its ion-exchanged derivatives Nano-X/Mn/0.5 M, Nano-X/Cu/0.5 M, Nano-X/Co/0.5 M, Nano-X/ $\mathrm{Zn} / 0.5 \mathrm{M}$ and Nano-X/Ni/0.5 M. The typical morphology and particle size of the synthesized Nano-X/Na (Fig. 4a) and its ionexchange derivatives (Figs. $4 \mathrm{~b}, \mathrm{~d}-\mathrm{f}$, respectively) were within the range of 20-100 $\mathrm{nm}$ and in accordance with the data reported by Zhan et al. $[25,26]$. The only exception was the SEM data obtained for Nano-X/Cu/0.5 M (Fig. 4c), whose particles size was within the range of 2 microns. The SEM data for the Nano-X/Cu/0.5 M sample were in agreement with the XRD data for this sample, which clearly indicated the formation of micrometric gismondine zeolites (Fig. 3). Low magnification TEM images of the synthesized Nano-X/Na (Fig. 5a) and Nano-X/Mn/0.5 M (Fig. 5b) revealed large nanoparticle aggregates of approximately $250 \mathrm{~nm}$, whereas Nano-X/Co/ $0.5 \mathrm{M}$ (Fig. 5d) and Nano-X/Zn/0.5 M (Fig. 5e) were formed from needle aggregates of approximately $500 \mathrm{~nm}$. On the other hand, high magnification TEM data for Nano-X/Ni/0.5 M (Fig. 5f) showed

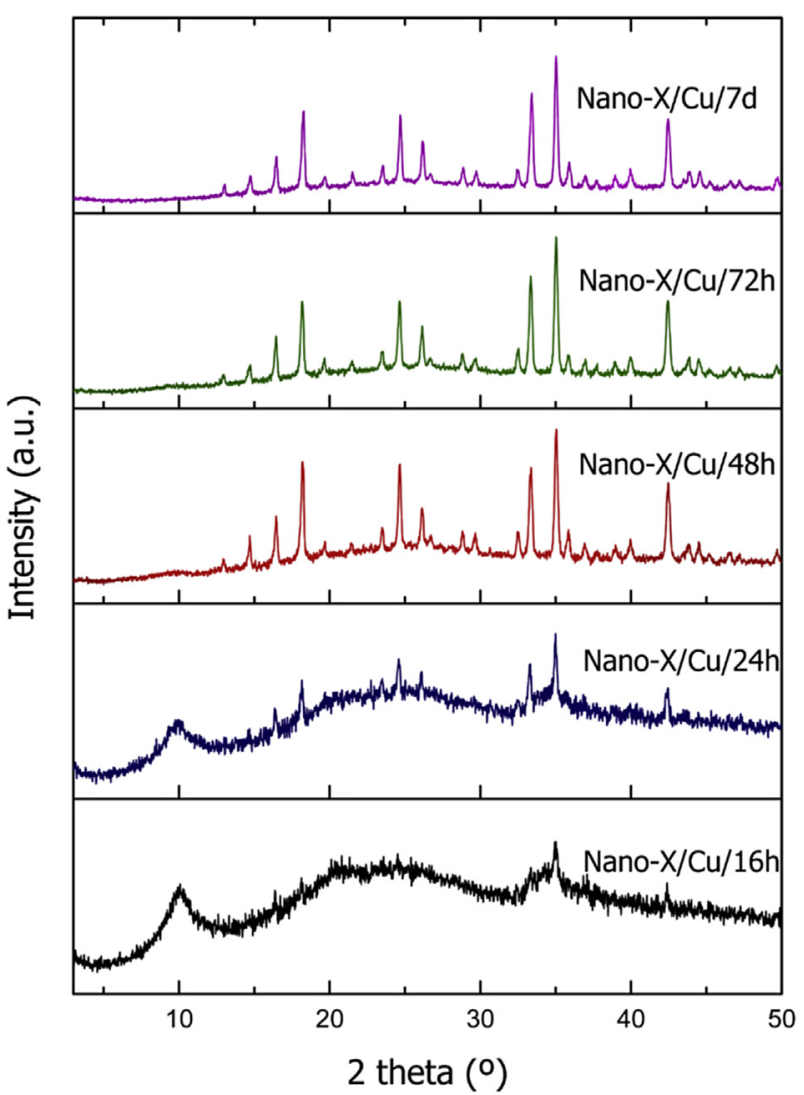

Fig. 3. XRD patterns of the zeolitic materials formed as $\mathrm{Cu}^{2+}$ acting as structure directing agents.

nanoparticles of approximately $20 \mathrm{~nm}$ (the whiter contrast) dispersed on the surface of the Nano-X/Ni/0.5 M sample, and EDX data have confirmed that these particle aggregates were nickel nanoparticles. In general, most methods reported in the literature producing $\mathrm{Ni}$ nanoparticles involve electrochemical reduction [58-60], chemical reduction [61-64], sol-gel [65], metal evaporation [64] and the use of organometallic precursors [64,66] and employ ion exchange and impregnation methods [67]. Nevertheless, it is clear from our experimental data set that the ion exchange treatment of the synthesized Nano-X/Na zeolite with nickel induced the formation of these nickel aggregates. The formation of these nickel nanometric aggregates was reproducible, and XPS analyses were carried out for these samples. XPS is a nondestructive method of investigation that allows the determination of the oxidation states of nickel species located on the zeolitic surface based on binding energies (BEs) and their related chemical shifts in the XPS spectra. Analyses of Ni $2 \mathrm{p}_{3 / 2}$ XPS spectra reported in the literature systematically assigned BEs of 852.6, 854.6 and $856.1 \mathrm{eV}$ toNi ${ }^{0}, \mathrm{Ni}^{2+}$ and $\mathrm{Ni}^{3+}$ in oxidized $\mathrm{Ni}$, hydroxides and oxyhydroxides, respectively [68]. The global $\mathrm{Ni} 2 \mathrm{p}_{3 / 2}$ XPS spectra of the Nano-X/Ni/ $0.5 \mathrm{M}$ sample is shown in Fig.6. The XPS spectra were fitted using the XPS chemical shifts of the following phases: $\mathrm{NiO}(854.0 \mathrm{eV})$, $\mathrm{Ni}(\mathrm{OH})_{2}(856.1 \mathrm{eV})$, and $\mathrm{Ni}_{2} \mathrm{O}_{3}(587 \mathrm{eV})$. The satellite structures of these phases were also taken into account for the spectrum fitting: $\mathrm{NiO}$ and $\mathrm{Ni}(\mathrm{OH})_{2}(\mathrm{Ni} \mathrm{II}, 858,7 \mathrm{eV}), \mathrm{Ni}_{2} \mathrm{O}_{3}(\mathrm{Ni} \mathrm{III}, 862.4$ and $864.4 \mathrm{eV})$. The preliminary analyses of the XPS data revealed that the chemical composition of Nano-X/Ni/0.5 M is complex, and it is possible that both $\mathrm{Ni}^{2+}$ and $\mathrm{Ni}^{3+}$ species coexist in the Nano-X/Ni/0.5 M sample. It is plausible that these nanometric nickel species might have played an important role in the synergistic behavior observed between $T$. lanuginosus and the Nano-X/Ni/0.5 M support. A more 

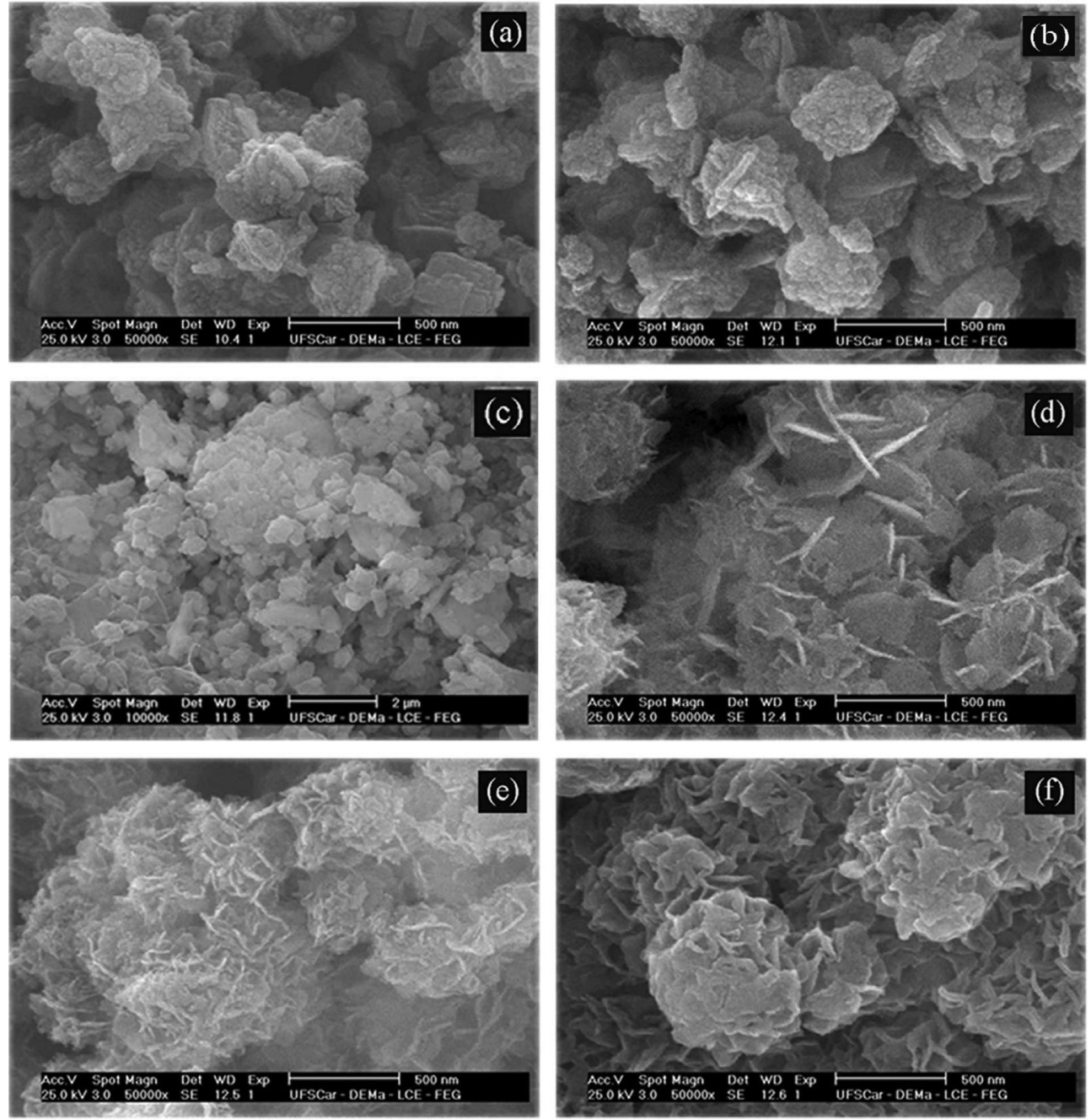

Fig. 4. SEM data for the samples Nano-X/Na (a), Nano-X/0.5 M/Mn(b), Nano-X/Cu 0.5 M (c), Nano-X/Co/0.5 M (d), Nano-X/Zn/0.5 M (e), Nano-X/Ni/0.5 M (f).

Table 1

Chemical compositions of the nanozeolitic supports obtained by ICP-AES

\begin{tabular}{|c|c|c|c|c|c|c|c|c|}
\hline Sample & $\mathrm{SiO}_{2}(\%)$ & $\mathrm{Al}_{2} \mathrm{O}_{3}(\%)$ & $\mathrm{Na}_{2} \mathrm{O}(\%)$ & $\mathrm{CuO}(\%)$ & $\mathrm{MnO}(\%)$ & $\mathrm{CoO}(\%)$ & $\mathrm{ZnO}(\%)$ & $\mathrm{NiO}(\%)$ \\
\hline Nano-X/Na & 33.23 & 20.84 & 13.97 & - & - & - & - & - \\
\hline Nano-X/Cu/0.5 M & 23.34 & 14.92 & 0.08 & 26.65 & - & - & - & - \\
\hline Nano-X/Mn/0.5 M & 31.14 & 20.24 & 1.92 & - & 14.68 & - & - & - \\
\hline Nano-X/Co/0.5 M & 28.29 & 18.47 & 0.72 & - & - & 18.01 & - & - \\
\hline Nano-X/Zn/0.5 M & 27.25 & 18.18 & 1.81 & - & - & - & 22.56 & - \\
\hline Nano-X/Ni/0.5 M & 18.23 & 12.83 & 0.12 & - & - & - & - & 14.88 \\
\hline
\end{tabular}

detailed characterization of these particle aggregates using more appropriate spectroscopic techniques, such as EXAFS, will be performed in the upcoming months [69].

AFM data were also collected for Nano-X/Ni/0.5 M and Nano-X/ $\mathrm{Ni} / \mathrm{TLL}$ (Fig. 7) because the best catalytic results were obtained with these nanozeolite-enzyme complexes. The AFM data clearly indicated a difference in topography between Nano-X/Ni/0.5 M (Fig. 7a and b) and Nano-X/Ni/0.5 M-TLL (Fig. 7c and d). In the case of Nano$\mathrm{X} / \mathrm{Ni} / 0.5 \mathrm{M}$ there were the formation of nanometric aggregates in the $250-500 \mathrm{~nm}$ range (Fig. 7b), while the AFM images of the Nano-X/Ni/0.5 M-TLL have revealed the formation of smaller nanometric aggregates around $100-150 \mathrm{~nm}$ (Fig.7c), and it was also observed different values of roughness for Nano-X/Ni/0.5 M $(13.47 \mathrm{~nm})$ and Nano-X/Ni/0.5 M-TLL (2.87 nm).
The specific surface area and external surface area of Nano-X/Na and its ion-exchanged derivatives were calculated based on t-plot analysis of the $\mathrm{N}_{2}$ adsorption isotherms and are displayed in Fig. 8. Table 1 provides the external surface area, the $\mathrm{N}_{2}$ adsorption of all of the nanozeolites, the amount of the lipases immobilized on the zeolitic supports and their enzymatic activity after immobilization.

It can be observed from the data displayed in Table 2 that there is no straightforward correlation between the external surface area of the nanozeolites, the amount of immobilized enzyme and enzymatic activity. For instance, Nano-X/Na $\left(114.61 \mathrm{~m}^{2} / \mathrm{g}\right)$ immobilized similar amounts of the enzymes from $R$. miehei (20.6\%) and T. lanuginosus (18.3\%). However, this behavior changed dramatically for the synthesized Nano-X/Na ion-exchanged derivatives. Nano-X/ $\mathrm{Mn} / 0.5 \mathrm{M}\left(94.5 \mathrm{~m}^{2} / \mathrm{g}\right)$ immobilized a greater amount of the 

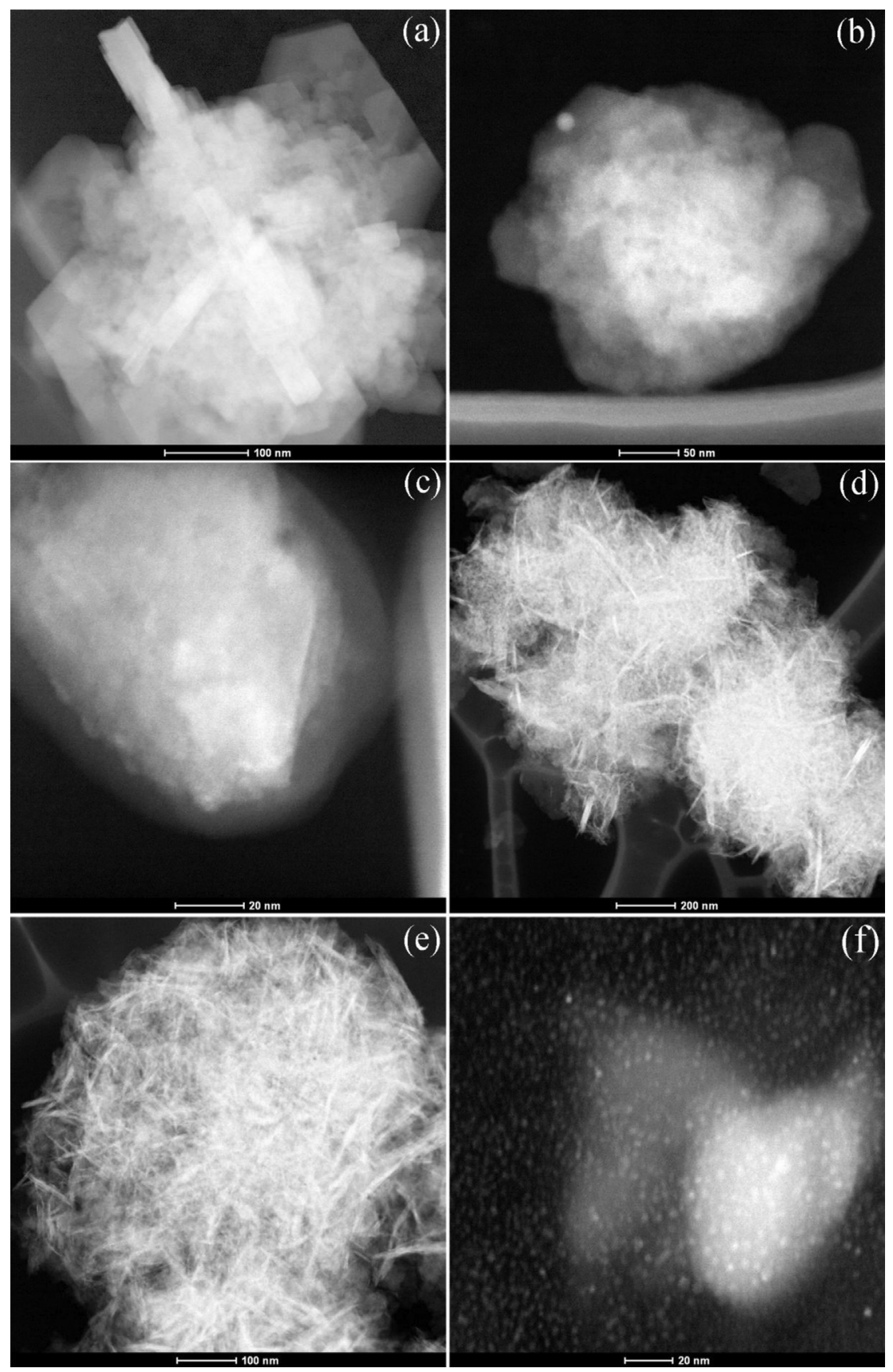

Fig. 5. TEM data for the samples Nano-X/Na (a), Nano-X/Mn/0.5 M(b), Nano-X/Cu/0.5 M (c), Nano-X/Co/0.5 M (d), Nano-X/Zn/0.5 M (e), Nano-X/Ni/0.5 M (f).

T. lanuginosus enzyme (77.5\%) in comparison with the amount of immobilized $R$. miehei (29.1\%) enzyme. Nano-X/Zn/0.5 $\mathrm{M}$ has an external surface area $\left(320.1 \mathrm{~m}^{2} / \mathrm{g}\right)$ that is three-fold larger than that of Nano-X/Mn/0.5 M (94.5 m²/g), but it immobilized a similar amount of the T. lanuginosus (90.8\%) and R. miehei (27.3\%) enzymes. On the other hand, Nano-X/Co/0.5 M $\left(341.4 \mathrm{~m}^{2} / \mathrm{g}\right)$ has immobilized the same amount of both $T$. lanuginosus (98.5\%) and $R$. miehei (98.3\%) enzymes. Nano-X/Ni/0.5 M (224.4 $\left.\mathrm{m}^{2} / \mathrm{g}\right)$ has also immobilized approximately similar amounts of the T. lanuginosus (43.7\%) and $R$. miehei (49.1\%) enzymes. At this point it is reasonable to assume that the adsorption of the enzymes did not occur inside the intracrystalline porous network of the zeolites, but on the external surface of the zeolitic supports. According to the X-ray crystallographic studies $T$. lanuginosus and $R$. miehei enzymes are roughly spherical in shape with sizes of $35 \AA \times 45 \AA \times 50 \AA$ [70] and $75 \AA \times 77 \AA \times 55 \AA$ [71] respectively and zeolite NaX has a porous apertures of $7-8 \AA$, therefore it is reasonable to assume that the enzymes can not penetrate this internal porosity and thus the adsorption of enzymes is bound to occur only on the external surface of the zeolitic supports.

The enzymatic activities of the nanozeolitic-enzyme complexes measured by the trimetric method varied from one nanozeolitic support to another, as shown in Table 2. Enzymatic activities of the free enzymes were measured by the p-NPP method. The enzymatic activities values and also the experimental reasons for using the $\mathrm{p}$ NPP method for the free enzymes are given in the supplementary data section. It is quite interesting that the Nano-X/Co/0.5 M supports, which immobilized the same amount of the $T$. lanuginosus 


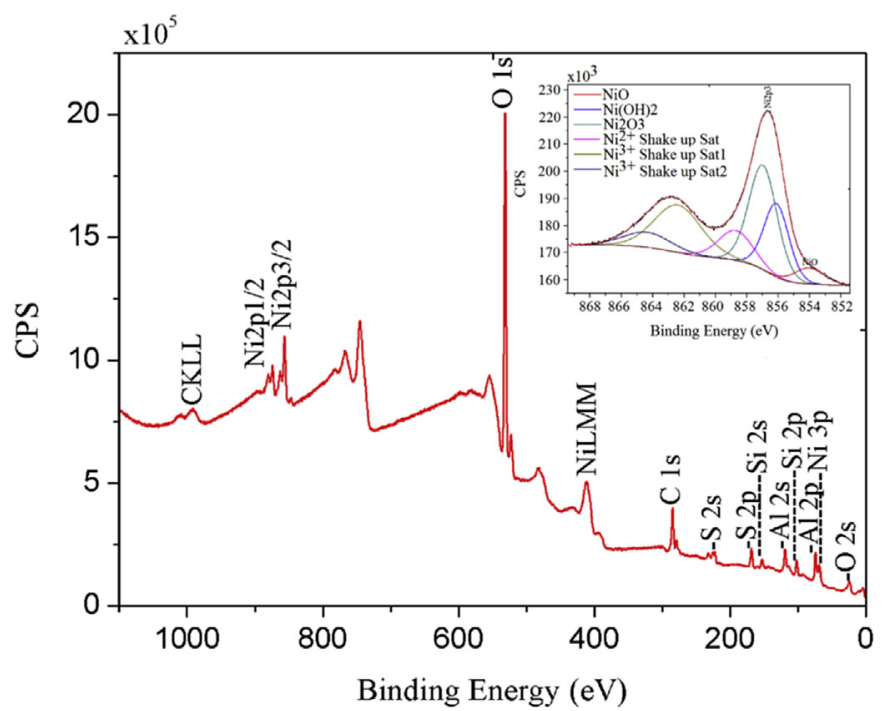

Fig. 6. Global and $\mathrm{Ni} 2 \mathrm{p}_{3 / 2}$ XPS data for the Nano-X/Ni/0.5 M sample.

(98.5\%) and $R$. miehei (98.3\%) enzymes, resulted in distinct enzymatic activities for the $T$. lanuginosus (24.8 $\mathrm{U}$ ) and $R$. miehei (5.6U) enzymes. This behavior was also observed for the Nano-X/Mn/ $0.5 \mathrm{M}$ and Nano-X/Zn/0.5 M, supports where higher enzymatic activities were also observed for the T. lanuginosus enzyme (28.4 U

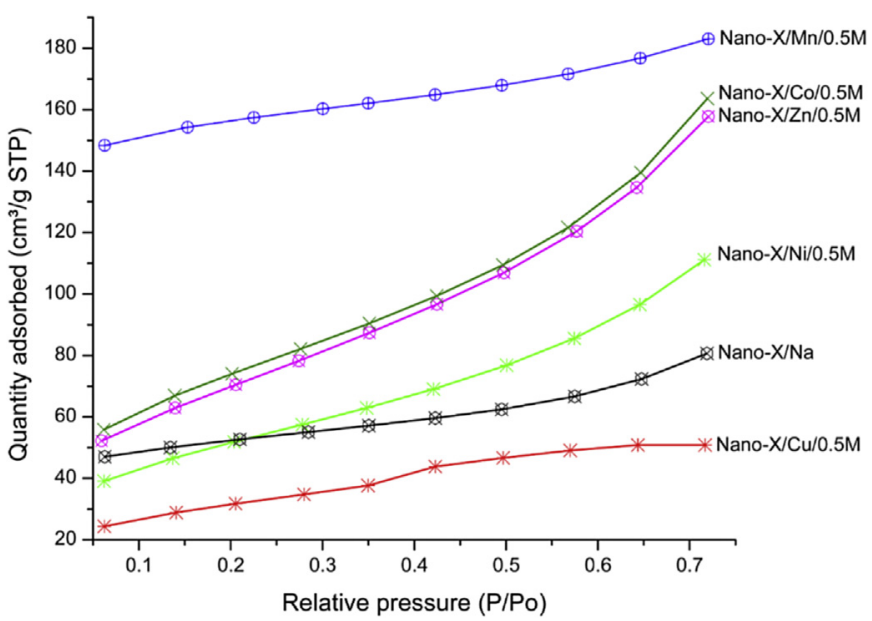

Fig. 8. BET data for the nanozeolitic supports.

and 25.2U, respectively). Meanwhile the lowest enzyme activities were observed for the $R$. miehei enzyme immobilized on Nano-X/ $\mathrm{Mn} / 0.5 \mathrm{M}$ (6.0 U) and Nano-X/Zn/0.5 M (9.2U).

Taking into consideration the experimental observations that the lowest enzymatic activities were obtained for the Nano-X/Na supports $(2.4 \mathrm{U})$ and highest for the Nano-X/Ni/0.5 M supports (44 $\mathrm{U}$ and $51.6 \mathrm{U}$ for $R$. miehei and T. lanuginosus, respectively), and
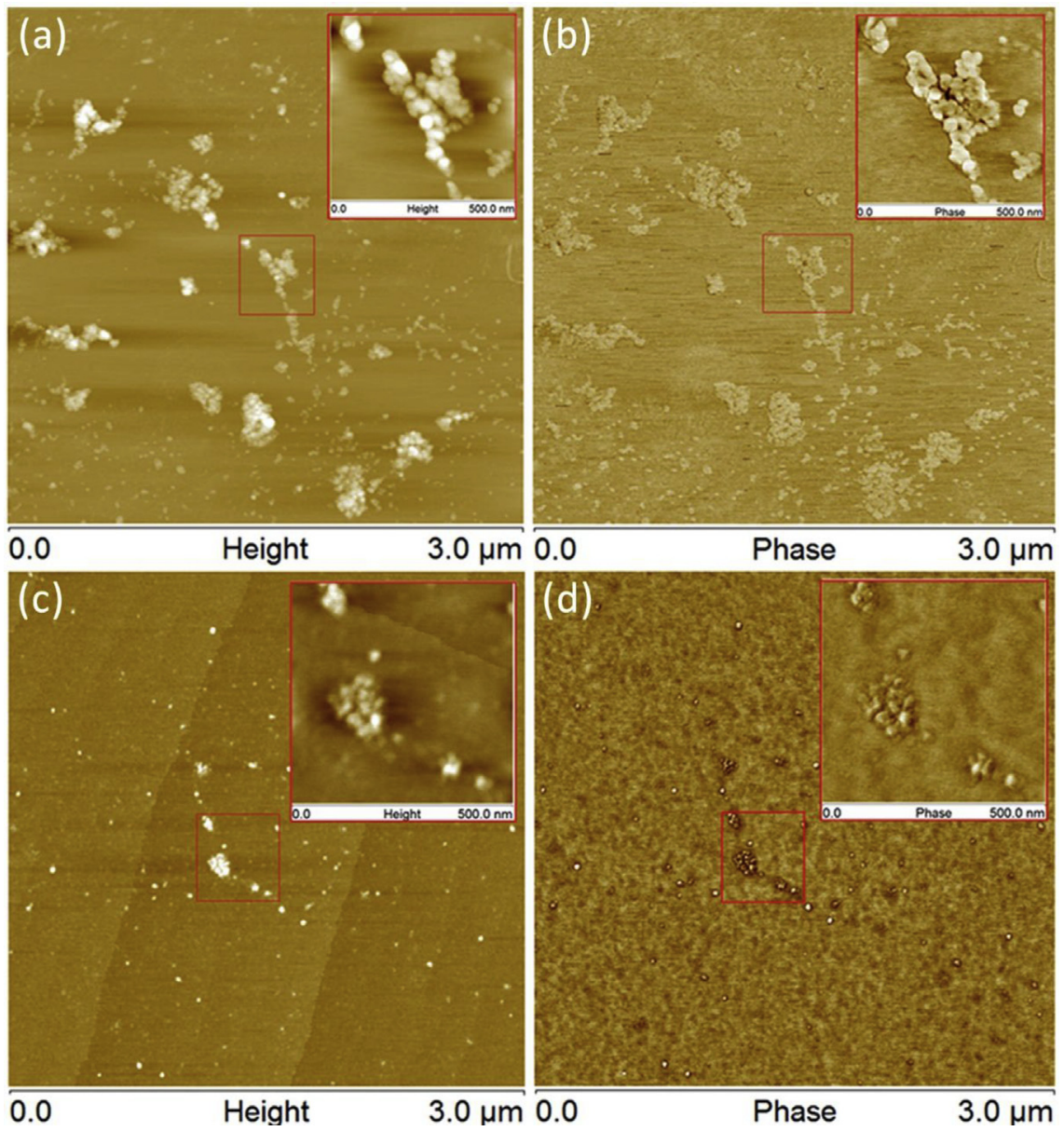

Fig. 7. Topography and phase images of AFM data for the Nano-X/Ni/0.5 M (a, b) and, Nano-X/0.5 M/Ni/TLL (c, d) 
Table 2

The external surface area, amount of lipases immobilized on the zeolitic supports and their enzymatic activity after immobilization.

\begin{tabular}{|c|c|c|c|c|}
\hline Nanozeolite & External surface area $\left(\mathrm{m}^{2} / \mathrm{g}\right)$ & Enzyme & Immobilization (\%) & Enzymatic activity (U/mg-support) \\
\hline \multirow[t]{2}{*}{ Nano-X/Na } & 114.6169 & R. miehei & $20.6 \pm 0.9$ & 3.2 \\
\hline & & T. lanuginosus & $18.3 \pm 2.1$ & 2.4 \\
\hline \multirow[t]{2}{*}{ Nano-X/Cu/0.5 M } & 44.3510 & R. miehei & $37.8 \pm 0.5$ & 8.0 \\
\hline & & T. lanuginosus & $68.4 \pm 4.1$ & 9.6 \\
\hline \multirow[t]{2}{*}{ Nano-X/Mn/0.5 M } & 94.5293 & R. miehei & $29.1 \pm 0.4$ & 6.0 \\
\hline & & T. lanuginosus & $77.5 \pm 0.9$ & 28.4 \\
\hline \multirow[t]{2}{*}{ Nano-X/Co/0.5 M } & 341.4066 & R. miehei & $98.3 \pm 0.8$ & 5.6 \\
\hline & & T. lanuginosus & $98.5 \pm 1.1$ & 24.8 \\
\hline \multirow[t]{2}{*}{ Nano-X/Zn/0.5 M } & 320.0833 & R. miehei & $27.3 \pm 0.8$ & 9.2 \\
\hline & & T. lanuginosus & $90.8 \pm 1.0$ & 25.2 \\
\hline \multirow[t]{2}{*}{ Nano-X/Ni/0.5 M } & 224.4474 & R. miehei & $49.1 \pm 1.2$ & 44.0 \\
\hline & & T. lanuginosus & $43.7 \pm 1.1$ & 51.6 \\
\hline
\end{tabular}

the other nanozeolitic supports derived from the ion exchange experiments showed enzymatic activities within the intermediate range (see Table 2), it is possible to conclude that the nature of the extra-framework cations plays an important role in the immobilization and activation of the enzymes during the immobilization process. Nevertheless, the experimental results obtained for the Nano-X/Ni/0.5 M supports are quite unusual because $\mathrm{Ni}^{2+}$ cations were able to activate both the T. lanuginosus (51.6 U) and $R$. miehei (44.0 U) enzymes in such a distinct and efficient manner compared with the other zeolitic supports. There is only one report in the literature describing similar behavior, which was observed for micrometric zeolites ion exchanged with $\mathrm{Ni}^{2+}$ [33]. However, a comparison of the enzymatic activities reported for micrometric zeolites with the present experimental data clearly indicated that this activation is more accentuated or enhanced when immobilization takes place on nickel ion-exchanged nanozeolitic supports.

Systematic catalytic studies examining the transesterification of palm oil into biodiesel were performed with the obtained nanozeolitic supports, nanozeolite-enzyme complexes and with the free $R$. miehei and $T$. lanuginosus enzymes, using an amount equivalent to the enzyme concentration immobilized on the nanozeolitic supports. The FAEE yields obtained for all of the synthesized nanozeolitic supports under these catalytic experimental conditions were less than $5 \%$. The FAEE yields obtained with the

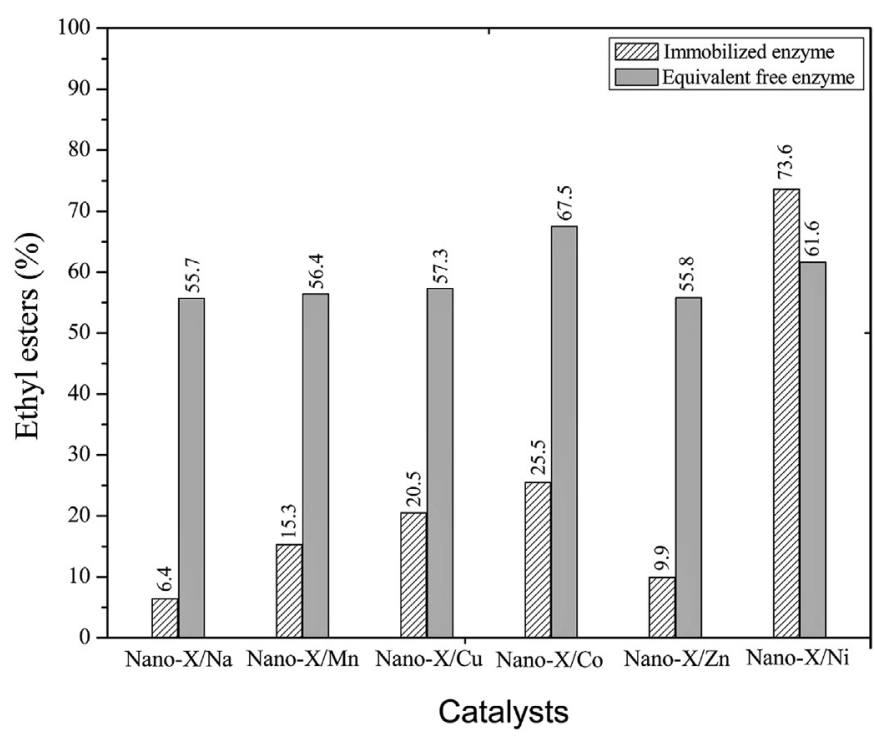

Fig. 9. Transesterification reactions systematic catalytic reactions using the equivalent amount of enzyme immobilized onto the nanozeolitic supports in its free form and the FAEEs yields obtained for Rhizomucor miehei lipase. free and immobilized enzymes are displayed in Figs. 9 and 10, respectively.

In the specific case of the R. miehei enzyme, it was systematically observed that the greatest amount of FAEEs was obtained using of the $R$. miehei enzyme in its free form in comparison with the equivalent amount of the enzyme immobilized on the Nano-X/Mn/ 0.5 M-RML, Nano-X/Cu/0.5 M-RML, Nano-X/Co/0.5 M-RML, and Nano-X/Zn/0.5 M-RML nanozeolitic supports (Fig. 9). The only exception was observed for the Nano-X/Ni/0.5 M-RML complex, which produced a lightly higher yield of FAEE (73.6\%) compared with the FAEE yield produced by the free enzyme (61.6\%).

On the other hand, the T. lanuginosus enzyme, in both its immobilized and free forms, behaved in a completely different manner (Fig. 10). The FAEE yields produced using the Nano-X/Mn/ 0.5 M-TLL, Nano-X/Co/0.5 M-TLL, and Nano-X/Zn/0.5 M-TLL complexes were similar to the FAEE yield obtained using the equivalent amount of $T$. lanuginosus in its free form. The only two exceptions were observed for Nano-X/Cu/0.5 M-TLL and Nano-X/Ni/0.5 M-TLL. In the case of the Nano-X/Cu/0.5 M-TLL complexes, the FAEE yield obtained from the complex was lower than yield obtained using the enzymes in their free forms, providing strong evidence that cupric cations are strong inhibitors of both enzymes, as has been reported elsewhere [33].

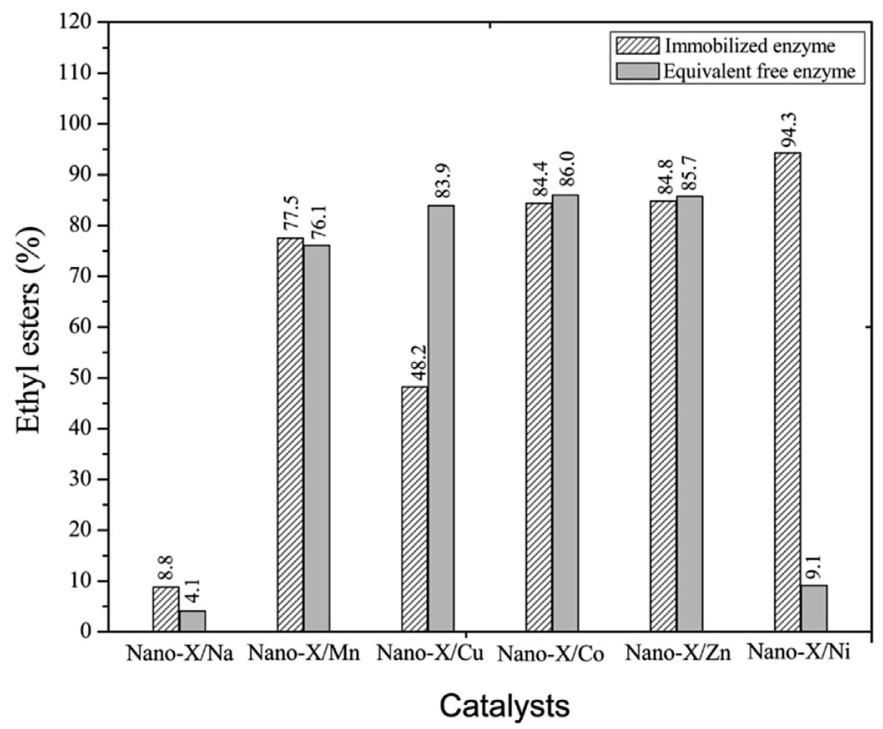

Fig. 10. Transesterification reactions systematic catalytic reactions using the equivalent amount of enzyme immobilized onto the nanozeolitic supports in its free form and the FAEEs yields obtained for Thermomyces lanuginosus. 
The other exception was observed for the Nano-X/Ni/0.5 M-TLL complexes, which displayed exceptional results, as the FAEE yield produced by the Nano-X/Ni/0.5 M-TLL complexes (94.3\%) was tenfold higher than the FAEE yield produced by the equivalent amount of $T$. lanuginosus enzyme in its free form (9.1\%). The experimental viscosities values obtained for both the palm oil and biodiesel produced with the Nano-X/Ni/0.5 M-TLL catalysts were $28.72 \pm 0.37$ and $4.97 \pm 0.03 \mathrm{cSt}$ respectively. The latter is in accordance with both the ASTM D6751 and EN14126 biodiesel standards that establish values in the ranges $1.9-6.0 \mathrm{cSt}$ and 3.0-5.0 cSt, respectively. Although the Nano-X/Ni/0.5 M-TLL complexes immobilized the lowest amount of the $T$. lanuginosus enzyme (43.7\%), these complexes resulted in the highest enzymatic activities (51.6 $\mathrm{U}$ ) in comparison with the other complexes investigated in this study. The Nano-X/Ni/0.5 M-TLL complexes were also stable and active after several turnovers. They were able to produce high yields of FAEEs for 3 cycles, and after 5 cycles, the FAEE yields remained steady at approximately $60 \%$ (Fig. 11). It was evident from these experimental data that a synergistic effect between the Nano$\mathrm{X} / \mathrm{Ni} / 0.5 \mathrm{M}$ zeolitic support and the $T$. lanuginosus enzyme had occurred, and some relevant questions were raised: What could be the possible reason for this unusual interaction between the Nano$\mathrm{X} / \mathrm{Ni} / 0.5 \mathrm{M}$ support and the T. lanuginosus enzyme? Why the synergistic effect observed for the Nano-X/Ni/0.5 M-TLL complexes during the transesterification reactions was not detected for the Nano-X/Ni/0.5 M-RML complexes?

To answer these questions, the bioinformatics approaches described in Sections 2.9 and 2.9.1 were employed. The objective was to gain insight into the dynamic behavior of the T. lanuginosus and $R$. miehei lipases. The crystallographic structures of both enzymes are available at the Protein Data Bank [72] under the IDs 1DT3 (T. lanuginosus) [73] and 3TGL (R. miehei) [74]. Each lipase is composed of 269 amino acid residues. Structurally, all known lipases are very similar. They are composed of an 8-strand beta spine flanked by coiled regions and by three long alpha helices and eight other shorter alpha helices (Fig. 12a).

The trypsin-like catalytic triad residues are Ser-146, Asp-201 and His-256, as shown in Fig. 12b. The T. lanuginosus lipase crystallographic structure is available in both its open and closed conformations. The closed conformation was chosen to explore the regions coupled to the opening of the enzyme's lid. The lid is composed of an alpha helix segment of catalytic residues and a lid region from Iso-86 to Leu-93 (Fig. 12c). Although the two lipases

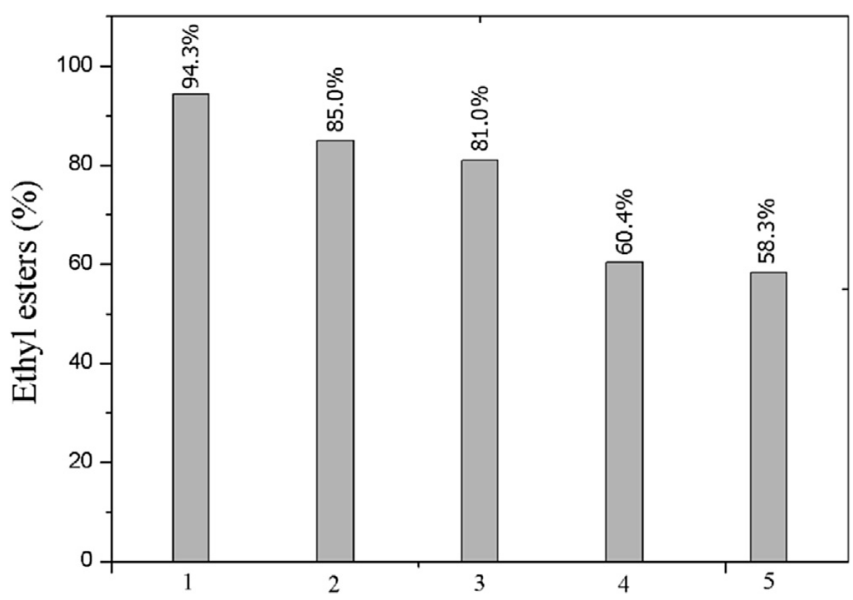

Turnover

Fig. 11. Turnover for the Nano-X/Ni/0.5 M-TLL complex. share a total of only 30\% (85 amino acid residues) of sequence similarity (Fig. 12d), the catalytic triad and lid region are totally conserved between them. The electrostatic potential surface (Fig. 13) indicates that there is a negatively charged region (red color, in the web version) present in both enzymes, whereas a relatively neutral region (white color), with some dispersed, positively charged sites (blue color, in the web version) is illustrated on the other side of the lipase structures. Nevertheless, the two enzymes exhibit different electrostatic patterns that influence their enzyme immobilization onto the zeolitic supports. In this case, these negatively charged regions of the enzymes could be potential binding sites for the nanozeolites with positively charged surfaces (see Table 3).

The dashed circles indicate the location of the protein's lids covering the entry to the catalytic triad, and in both enzymes, the lid provides a neutral region on the electrostatic potential surface. Due to the existence of these neutral regions for both enzymes, a possible enhancement of the catalytic activity promoted by a nanozeolite-enzyme complex would occur only if an allosteric mechanism regulating this nanozeolite-enzyme interaction were taken into consideration. To verify whether such a mechanism could exist in principle, a bioinformatic approach using normal mode simulations was applied.

Normal mode analysis (Fig. 14) illustrates the most probable movement relating the enzyme's negatively charged region and lid opening for the T. lanuginosus lipase. The negatively charged amino acid residue Asp-102 lies in the extension of the lid region, with another aspartic acid residue (Asp-158) being structurally situated near the aforementioned region (although this amino acid residue is not a lid extension component), and both amino acid residues are major contributors to the negative charges in this area. In principle, the interaction between this specific negative region of the enzyme and the positively charged zeolite can lead to the stabilization of the enzyme in its open conformation, consequently leaving the catalytic triad permanently exposed to the solvent.

The displacement of the lid from its initial to its final coordinates was measured based on the $C \alpha$ root mean square deviation, which is a standard method that is usually employed for the comparison of protein structures. It was found to vary from 1.3 to $2.0 \AA$, depending on the position of the observed amino acid residue. According to the proposed mechanism, zeolites with a negative zeta potential would not interact with the lipase binding site composed of Asp-102 and Asp-158, thus leading to poor catalytic activity, as was observed for the Nano-X/Na zeolites (see Table 2). The allosteric mechanism also explains why the Nano-X/Mn/0.5 MTLL, Nano-X/Co/0.5 M-TLL and Nano-X/Zn/0.5 M-TLL complexes yielded similar amounts of FAEEs to the equivalent amount of the enzymes in their free form because the enzymes were immobilized in their open conformation, as predicted by the allosteric model (see Fig. 10).

Although the Nano-X/Cu/0.5 M nanozeolitic support is positively charged, as are the other supports, the low FAEE yield observed for the Nano-X/Cu/0.5 M-TLL complex can be attributed to the toxicity of copper ions to lipases, as reported in the literature [33], [75-77]. This dynamic behavior was not observed for the R. miehei lipase, as the Nano-X/Mn/0.5 M-RML, Nano-X/Cu/0.5 MRML, Nano-X/Co/0.5 M-RML and Nano-X/Zn/0.5 M-RML complexes yielded lower FAEEs contents than the $R$. miehei enzyme in its free form (see Fig. 9). Interestingly, the lipase from $R$. miehei does not harbor the key aspartic acid residue at position 102, as shown in the sequence alignment of the two lipases (Fig. 12d). The lack of this specific amino acid residue precludes the enzyme from immobilized onto the zeolitic support in its open conformation.

Comparison of the allosteric model proposed in this study with other models reported in the literature will reveal important 


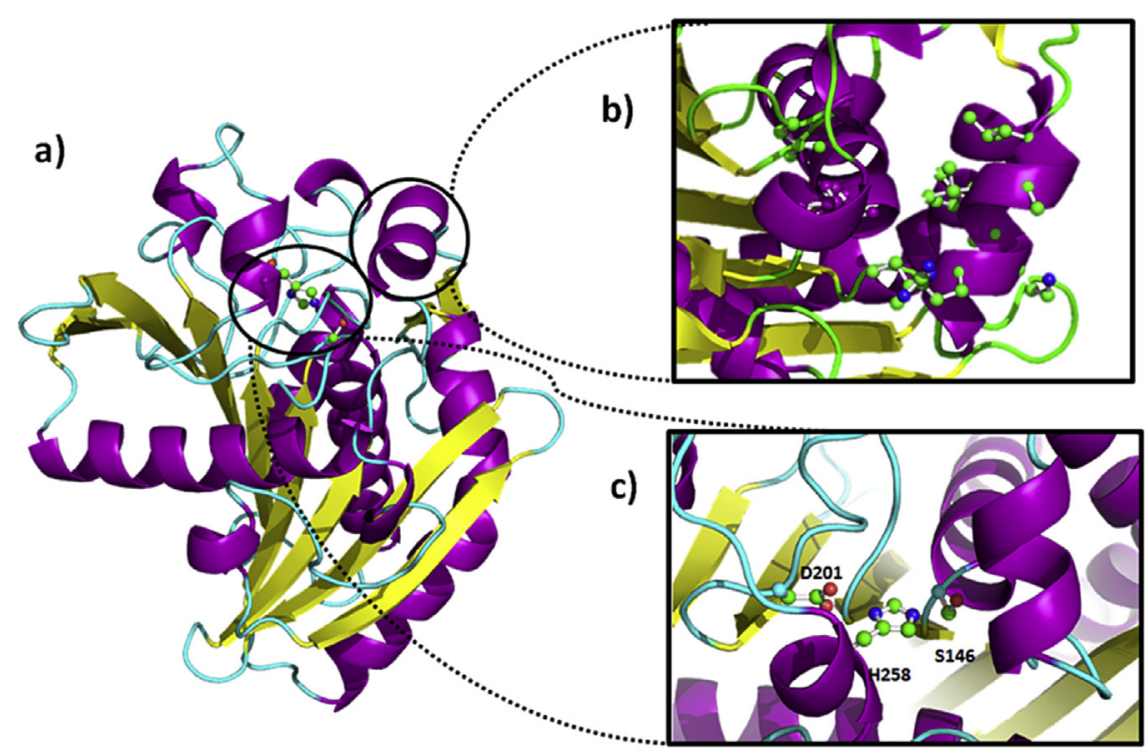

d)

T.lanuginosus EVSQDLFNQFNLFAQYSAAAYCGKNNDAPAGTNITCTGNACPEVEKADATFLYSFEDSGV 60 R.miehei -ATSOEINELTYYTTLSANSYCRTVIPGATWDCIHCDATEDLKIIKTWSTLIY------- 52

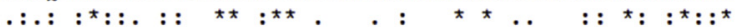

T.lanuginosus GDVTGFLALDNTNKLIVLSFRGSR IENWIGNLNFDLKEINDICSGCRGHDGFTSSWRSV 120 R.miehei -DTNAMVARGDSEKTIYIVFRGSSSIRNWIADITFVPVSYH-PVSGTKVHKGFLDSYGEV 110

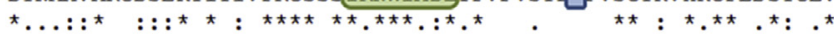

T.lanuginosus ADTLRQKVEDAVREHPDYRVVFTGSSLGGALATVAGADLRGNG-----YDIDVFSYGAPR 175 R.miehei QNELVATVLDQFKQYPSYKVAVTGE SLGGATALICALDLYQREEGLSSSNLFLYTQGQPR 170

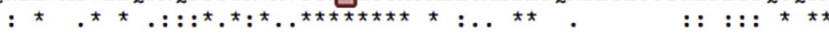

T.lanuginosus VGNRAFAEFLTVQTGGTLYRITHTY DIVPRLPPREFGYSHSSPEYWIKSGTLVPVTRNDI 235 R.miehei VGDPAFANYVV-STGIPYRRTVNEH IVPHLPPAAFGFLHAGEEYWITDNSPETVQVCT- 228

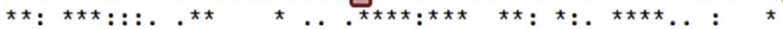

T.lanuginosus VKIEGIDATGGNNQPNIPDIPA A.WYFGLI-GTCL 269

R.miehei SDLET--SDCSNSIVPFTSVLDHSSYFGINTGLCT 261

$.: \quad: \quad * \quad: \quad .: * \star * \star *: * \star$

Catalytic residues $\square$ Lid region $\quad \square$ Aspartic acid (102)

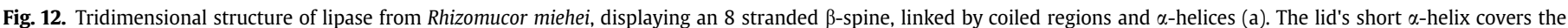

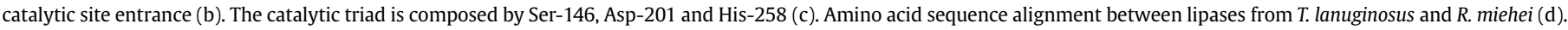

differences between them. For instance, Macario et al. [29] explained lipase-zeolite interactions based on electrostatic interactions and covalent bonding models. According to their model, the residual amino acid arginine-86, which is located at the edge of the lipase lid, would play a key role in the immobilization of the $R$. miehei lipase. Nevertheless, the proposed model is mainly speculative, and there are no available experimental or bioinformatic simulations to support it. Although Herrgard et al. [78] indicated that arginine-86 was responsible for the stabilization of the open/closed conformation of the lipase, it is not clear how the zeolitic support would interact with this specific amino acid residue to increase the catalytic rate.

On the other hand, the allosteric model proposed here is based on a macromolecular simulation that explains the experimental results. The model combines the surface electrostatic potential of the selected enzymes and normal mode analysis to elucidate a synergistic effect originating from the movements between lid opening and allosterically negative regions. The model is sufficiently plausible to explain the differences in the experimental results obtained for the $T$. lanuginosus and $R$. miehei lipases immobilized on the nanozeolitic supports investigated in this study.
The increase in the FAEE yield observed for the Nano-X/Ni/ $0.5 \mathrm{M}-\mathrm{RML}$ complex was not as significant as the increase observed for the Nano-X/Ni/0.5 M-TLL complexes, due to the lack an aspartic acid residue at position 102, as explained by the allosteric mechanism. Nevertheless the fact that the Nano-X/Ni/0.5 M-TLL complexes have increased the FAEE yield 10 -fold clearly indicates that this unusual enhancement of FAEE production may also be influenced by the formation of the nickel nanometric particle aggregates observed on the Nano-X/Ni/0.5 M supports, as shown in the TEM images (Fig. 5f).

Although there are several reports in the literature describing the role of cationic species such as $\mathrm{Ca}^{2+}, \mathrm{Fe}^{2+}$, and $\mathrm{Mg}^{2+}$ in the activation of lipases in solution, the role and effect of the nickel species in promoting or enhancing the activation of enzymes have not yet been properly investigated, and the few studies reported in the literature state that nickel species in solution generally have the effect of causing the deactivation of lipases [75-77]. It is important to note that the importance of nickel in biological systems was long unrated, until the discovery of urease as a nickel enzyme and other important enzymes such as methyl-coenzyme M (methyl-CoM) reductase (MCR), Ni-Fe hydrogenase, nickel-containing carbon 
a)
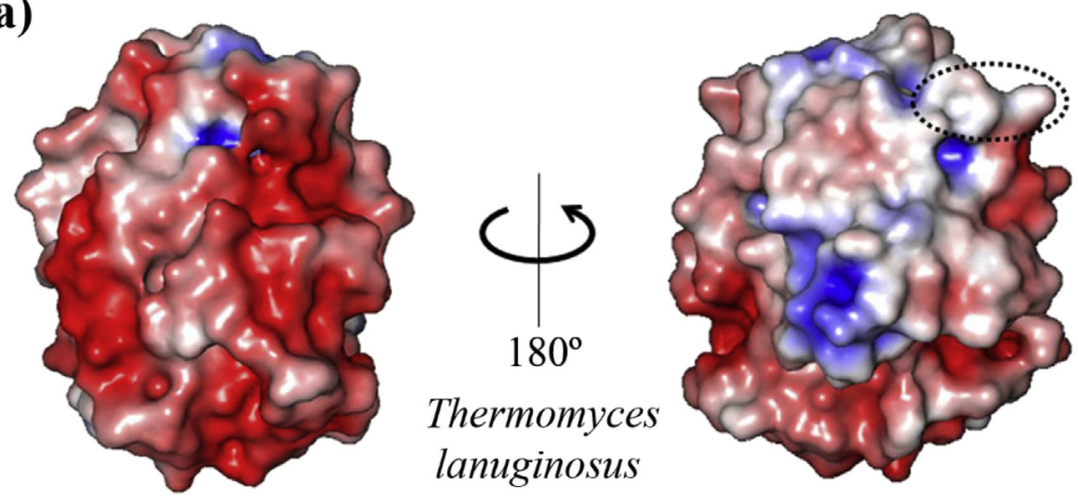

b)
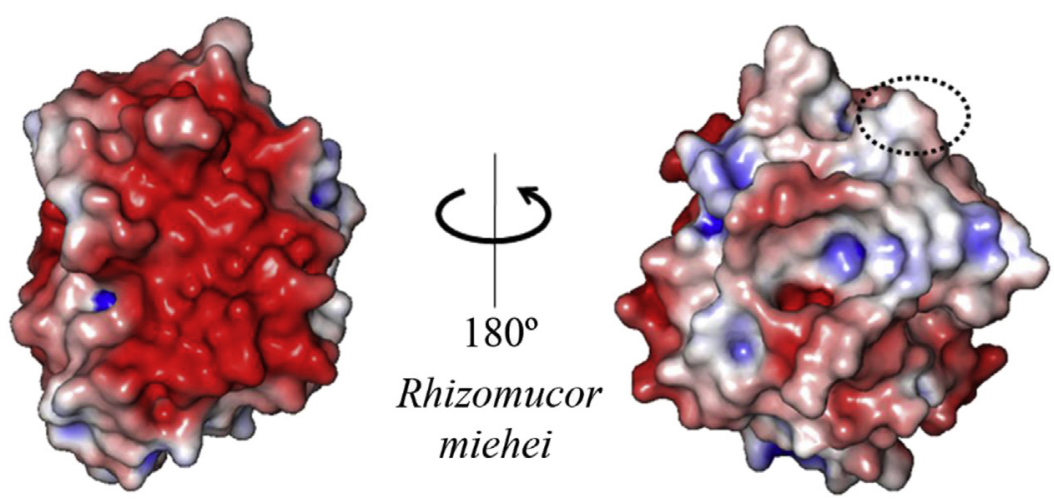

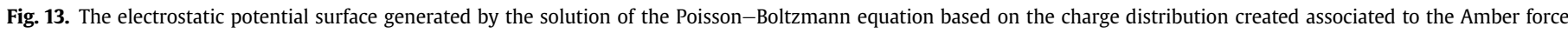
field. The dashed circles show the lids location. Illustration generated in PyMol.

Table 3

Zeta potential for the nanozeolitic supports.

\begin{tabular}{lll}
\hline Nanozeolite & Zeta potential $(\mathrm{mV})$ & Standard deviation $( \pm \mathrm{mV})$ \\
\hline Nano-X/Na & -50.9 & 0.2 \\
Nano-X/Cu/0.5 M & +13.7 & 0.2 \\
Nano-X/Mn/0.5 M & +41.0 & 0.3 \\
Nano-X/Co/0.5 M & +41.5 & 1.0 \\
Nano-X/Zn/0.5 M & +16.6 & 0.2 \\
Nano-X/Ni/0.5 M & +3.7 & 0.9 \\
\hline
\end{tabular}

monoxide dehydrogenase (NiCoDH), acetyl coenzyme A (acetyl_CoA) synthase (ACS), nickel_containing superoxide dismutase (NiSOD) and CO dehydrogenase [79-81]. Although these studies were not specifically related to lipase enzymes, our experimental results systematically showed that nanozeolitic solid supports treated with nickel consistently activated lipases in a very specific manner. In the case of the T. lanuginosus enzyme, this activation was greatly enhanced by the specificity of its crystallographic structure and the positively charged zeolitic surface, as suggested by the allosteric mechanism discussed above. This unique interaction observed for the T. lanuginosus enzyme and the nanozeolitic support treated with nickel is a strong indication that several of the drawbacks related to the use of free enzymes for the production of biodiesel can be overcome by employing these nanozeolite-enzyme complexes as catalysts. Therefore, further steps of this research will focus in finding commercial application for the use of this catalyst in the biodiesel industry where the volume of oil to be processed is in million metric tons. Scale up options exploring different configurations of enzymatic reactors such as the continuous stirred tank reactors; fixed bed column reactor (in which the
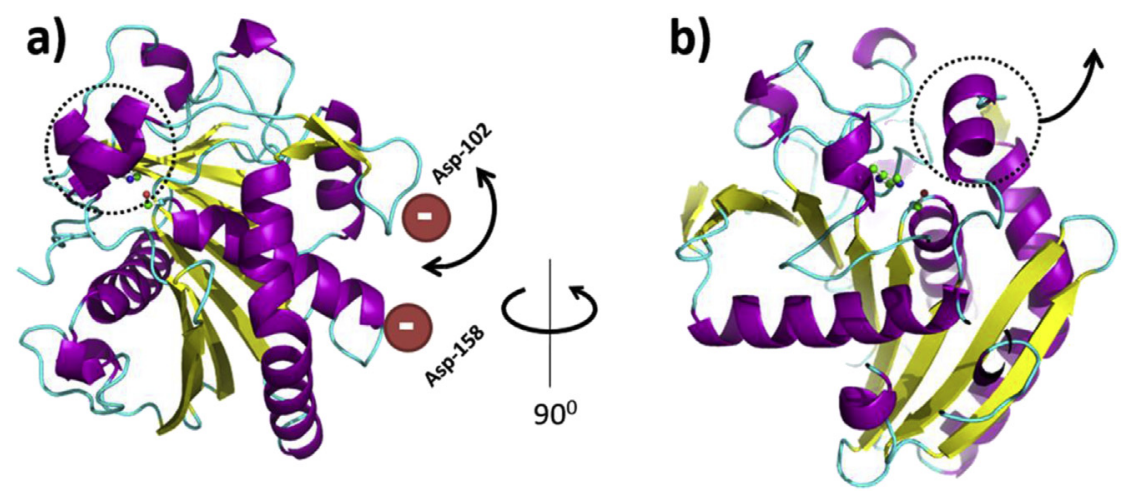

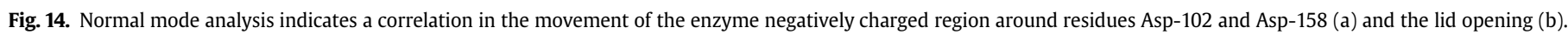
The amino acid residue Asp-102 is an extension of the lid backbone, resulting in its opening. 
immobilized enzyme is packed remaining stationary while the substrate solution is pumped through it); and the fluidized bed column reactor (in which the immobilized enzyme is kept suspended by means of recycling of the substrate solution pumped through) will be evaluated $[82,83]$.

\section{Conclusions}

- The amount of enzyme immobilized and its enzymatic activity depend on the nature of the extra-framework cation in the zeolitic supports.

- Although all of the zeolite-enzyme complexes derived from $T$. lanuginosus and $R$. miehei lipases were able to catalyze the transesterification of palm oil into biodiesel, the best catalytic performance was obtained with the Nano-X/Ni/0.5 M-TLL complex.

- A synergetic effect was observed due to the interaction between the positively charged surface of the zeolitic supports treated with $\mathrm{Ni}^{2+}$ and the $T$. lanuginosus enzyme in the transesterification reactions.

- A model of an allosteric mechanism generated using bioinformatics tools was proposed to explain this synergetic effect, and according to this model, the observed synergy is due to the interaction between aspartic acid residues 102 and 158 of the T. lanuginosus lipase and the positively charged zeolite surface.

- The lack of synergy systematically observed for the nanozeolite-complexes derived from the $R$. miehei lipase is due to the absence of the aspartic acid residue at position 102.

- Biocatalysts prepared with nanozeolitic supports ion exchanged with nickel and the T. lanuginosus enzyme are viable catalysts for the production of biodiesel.

\section{Acknowledgments}

This ongoing research project is financially supported by The State of São Paulo Research Foundation (FAPESP) in the form of a scientific award, 11/51851-5 (J.G.N.), and a graduate fellowship (A. Vasconcellos, 11/10092-4).We also thank CAPES and the National Council for Scientific and Technological Development (CNPq) for financial support under awards 406761/2013-2.

\section{Appendix A. Supplementary data}

Supplementary data related to this article can be found at http:// dx.doi.org/10.1016/j.micromeso.2015.05.007.

\section{References}

[1] F.R. Ma, M.A. Hanna, Bioresour. Technol. 70 (1999) 1-15.

[2] L.C. Meher, D.V. Sagar, S.N. Naik, Renew. Sustain. Energy Rev. 10 (2006) $248-268$.

[3] P.T. Vasudevan, M. Briggs, J. Ind. Microbiol. Biotechnol. 35 (2008) 421-430.

[4] D.-W. Lee, Y.-M. Park, K.-Y. Lee, Catal. Surv. Asia 13 (2009) 63-77.

[5] M. Di Serio, R. Tesser, L. Pengmei, E. Santacesaria, Energy Fuels 22 (2008) 207-217.

[6] S. Zheng, M. Kates, M.A. Dube, D.D. McLean, Biomass Bioenergy 30 (2006) 267-272.

[7] N.U. Soriano Jr., R. Venditti, D.S. Argyropoulos, Fuel 88 (2009) 560-565.

[8] Y. Shimada, Y. Watanabe, T. Samukawa, A. Sugihara, H. Noda, H. Fukuda, Y. Tominaga, J. Am. Oil Chem. Soc. 76 (1999) 789-793.

[9] L. Fjerbaek, K.V. Christensen, B. Norddahl, Biotechnol. Bioeng. 102 (2009) 1298-1315.

[10] W. Du, W. Li, T. Sun, X. Chen, D. Liu, Appl. Microbiol. Biotechnol. 79 (2008) $331-337$.

[11] W. Parawira, Crit. Rev. Biotechnol. 29 (2009) 82-93.

[12] A. Bajaj, P. Lohan, P.N. Jha, R. Mehrotra, J. Mol. Catal. B Enzym. 62 (2010) 9-14.

[13] M. Szczesna-Antczak, A. Kubiak, T. Antczak, S. Bielecki, Renew. Energy 34 (2009) 1185-1194.
[14] S. Brinbaum, in: I.A. Veliky, R.J.C. Mclean (Eds.), Immobilized Biosystems: Theory and Practical Application, Blackie Academic and Professional, USA, 1994.

[15] A. Macario, G. Giordano, P. Frontera, F. Crea, L. Setti, Catal. Lett. 122 (2008) 43-52.

[16] A. Corma, V. Fornes, F. Rey, Adv. Mater. 14 (2002) 71-74.

[17] J.F. Diaz, K.J. Balkus, J. Mol. Catal. B Enzym. 2 (1996) 115-126.

[18] M.E. Gimon-Kinsel, V.L. Jimenez, L. Washmon, K.J. Balkus Jr., Studies in Surface Science and Catalysis 117 (1998) 373-380.

[19] Y.J. Han, G.D. Stucky, A. Butler, J. Am. Chem. Soc. 121 (1999) 9897-9898.

[20] L. Tosheva, V.P. Valtchev, Chem. Mater. 17 (2005) 2494-2513.

[21] J.Y. Zhang, X. Zhou, J. Kong, Y. Tang, B. Liu, Anal. Chem. 80 (2008) 2457-2463.

[22] T. Yu, Y. Zhang, C. You, J. Zhuang, B. Wang, B. Liu, Y. Kang, Y. Tang, Chemistry 12 (2006) 1137-1143.

[23] R. Nenkova, J. Wu, Y. Zhang, T. Godjevargova, Anal. Biochem. 439 (2013) $65-72$.

[24] Y.J. Kang, W. Shan, J.Y. Wu, Y.H. Zhang, X.Y. Wang, W.L. Yang, Y. Tang, Chem. Mater. 18 (2006) 1861-1866.

[25] B.Z. Zhan, M.A. White, K.N. Robertson, T.S. Cameron, M. Gharghouri, Chem. Commun. (2001) 1176-1177.

[26] B.Z. Zhan, M.A. White, M. Lumsden, J. Mueller-Neuhaus, K.N. Robertson, T.S. Cameron, M. Gharghouri, Chem. Mater. 14 (2002) 3636-3642.

[27] U. Hölker, M. Höfer, J. Lenz, Appl. Microbiol. Biotechnol. 64 (2004) 175-186.

[28] F. Yagiz, D. Kazan, A.N. Akin, Chem. Eng. J. 134 (2007) 262-267.

[29] A. Macario, G. Giordano, L. Setti, A. Parise, J.M. Campelo, J.M. Marinas, D. Luna, Biocatal. Biotransform. 25 (2007) 328-335.

[30] M.M. Bradford, Anal. Biochem. 72 (1976) 248-254.

[31] U.K. Winkler, M. Stuckmann, J. Bacteriol. 138 (1979) 663-670.

[32] N. Gomes, C. Goncalves, M. Garcia-Roman, J.A. Teixeira, I. Belo, Anal. Methods 3 (2011) 1008-1013.

[33] A. de Vasconcellos, A.S. Paula, R.A. Luizon, L.A. Farias, E. Gomes, D.A.G. Aranda, J.G. Nery, Microporous Mesoporous Mater. 163 (2012) 343-355.

[34] Titration Was Performed by Following the Protocol Established for Chloramine T: Reagent Chemicals: American Chemical Society Specifications, eighth ed., American Chemical Society, Washington, DC, 1993, pp. 242-244.

[35] P. Gupta, L.S.B. Upadhyay, R. Shrivastava, Res. J. Microbiol. 6 (2011) 281-288.

[36] R. Spera, P. Ghisellini, E. Pechkova, V. Sivozhelezov, C. Nicolini, Adv. Energy Res. 9 (2011) 243-258. Nova Science Publisher.

[37] P. Pinsirodom, K.L. Parkin, in: Current Protocols in Food Analytical Chemistry, John Wiley \& Sons, New York, 2001, pp. C3.1.1-C3.1.13.

[38] K.S. Yang, J.-H. Sohn, H.K. Kim, J. Biosci. Bioeng. 107 (2009) 599-604.

[39] T.J. Dolinsky, J.E. Nielsen, J.A. McCammon, N.A. Baker, Nucleic Acids Res. 32 (2004) 665-667.

[40] K. Lindorff-Larsen, S. Piana, K. Palmo, P. Maragakis, J.L. Klepeis, R.O. Dror, D.E. Shaw, Proteins 78 (2010) 1950-1958.

[41] N.A. Baker, D. Sept, S. Joseph, M.J. Holst, J.A. McCammon, Proc. Natl. Acad. Sci. 98 (2001) 10037-10041.

[42] The PyMOL Molecular Graphics System, Version 1.5.0.4 Schrödinger, LLC

[43] I. Bahar, T.R. Lezon, A. Bakan, I.H. Shrivastava, Chem. Rev. 110 (2010) 1463-1497.

[44] J. Ponder, TINKER Software Tools for Molecular Design, Version 4.1, Washington University School of Medicine, 2003. Available from: http://dasher. wustl.edu/tinker.

[45] S. Ronchetti, E.A. Turcato, A. Delmastro, S. Esposito, C. Ferone, M. Pansini, B. Onida, D. Mazza, Mater. Res. Bull. 45 (2010) 744-750.

[46] C. Wang, H. Shi, Y. Li, Appl. Surf. Sci. 257 (2011) 6873-6877.

[47] C. Covarrubias, F. Gracia, H. Palza, Appl. Catal. A Gen. 384 (2010) 186-191.

[48] D.M. El-Mekkawi, M.M. Selim, Mater. Charact. 69 (2012) 37-44.

[49] S. Hashimoto, J. Photochem. Photobiol. C Photochem. Rev. 4 (2003) 19-49.

[50] M.M.J. Treacy, J.B. Higgins, R.V. Ballmoos, Collection of Particle Size Is Approximately $300 \mathrm{~nm}$ for the Sample Judged to Simulated XRD Powder Patterns for Zeolites, third ed., Elsevier, New York, 1996.

[51] R.M. Barrer, Zeolites 1 (1981) 130-140.

[52] M.E. Davis, R.F. Lobo, Chem. Mater. 4 (1992) 756-768.

[53] B.M. Lok, T.R. Cannan, C.A. Messina, Zeolites 3 (1983) 282-291.

[54] C.S. Cundy, P.A. Cox, Microporous Mesoporous Mater. 82 (2005) 1-78.

[55] C.S. Cundy, P.A. Cox, Chem. Rev. 103 (2003) 663-702.

[56] R.M. Barrer, Hydrothermal Chemistry of Zeolites, Academic Press, London; New York, 1982.

[57] Edith M. Flanigen, Molecular Sieves, American Chemical Society, 1973, pp. 119-139.

[58] T. Umegaki, J.-M. Yan, X.-B. Zhang, H. Shioyama, N. Kuriyama, Q. Xu, J. Power Sources 191 (2009) 209-216.

[59] M.T. Reetz, W. Helbig, J. Am. Chem. Soc. 116 (1994) 7401-7402.

[60] Y. Hou, H. Kondoh, T. Ohta, S. Gao, Appl. Surf. Sci. 241 (2005) 218-222.

[61] S.R. Hoon, M. Kilner, G.J. Russell, B.K. Tanner, J. Magn. Magn. Mater. 39 (1983) $107-110$.

[62] T. Bein, S.J. McLain, D.R. Corbin, R.D. Farlee, K. Moller, G.D. Stucky, G. Woolery, D. Sayers, J. Am. Chem. Soc. 110 (1988) 1801-1810.

[63] N. Cordente, C. Amiens, B. Chaudret, M. Respaud, F. Senocq, M.J. Casanove, J. Appl. Phys. 94 (2003) 6358-6365.

[64] T.O. Ely, C. Amiens, B. Chaudret, E. Snoeck, M. Verelst, M. Respaud, J.-M. Broto, Chem. Mater. 11 (1999) 526-529.

[65] J. Gong, L.L. Wang, Y. Liu, J.H. Yang, Z.G. Zong, J. Alloys Compd. 457 (2008) 6-9.

[66] C.B. Murray, S. Sun, H. Doyle, T. Betley, MRS Bull. 26 (2001) 985-991. 
[67] B. Coughlan, M.A. Keane, Zeolites 11 (1991) 2-11.

[68] A.P. Grosvenor, M.C. Biesinger, R.S.C. Smart, N.S. McIntyre, Surf. Sci. 600 (2006) 1771-1779.

[69] Research Proposal to be submitted to the Brazilian Synchrotron Light Laboratory (LNLS) for performing EXAFS experiments using the LNLS XAFS-1.

[70] R. Fernandez-Lafuente, J. Mol. Catal. B Enzym. 62 (2010) 197-212.

[71] Z.S. Derewenda, U. Derewenda, G.G. Dodson, J. Mol. Biol. Engl. 227 (1992) 818-839.

[72] H.M. Berman, T.N. Bhat, P.E. Bourne, Z. Feng, G. Gilliland, H. Weissig J. Westbrook, Nat. Struct. Biol. 7 (Suppl.) (2000) 957-959.

[73] A.M. Brzozowski, H. Savage, C.S. Verma, J.P. Turkenburg, D.M. Lawson, A. Svendsen, S. Patkar, Biochemistry 39 (2000) 15071-15082.

[74] A.M. Brzozowski, Z.S. Derewenda, E.J. Dodson, G.G. Dodson, J.P. Turkenburg, Acta Crystallogr. Sect. B 48 (1992) 307-319.

[75] M. Riaz, A.A. Shah, A. Hameed, F. Hasan, Ann. Microbiol. 60 (2010) 169-175.
[76] P.S. Borkar, R.G. Bodade, S.R. Rao, C.N. Khobragade, Braz. J. Microbiol. 40 (2009) 358-366.

[77] R. Sharma, S.K. Soni, R.M. Vohra, L.K. Gupta, J.K. Gupta, Process Biochem. 37 (2002) 1075-1084.

[78] S. Herrgard, C.J. Gibas, S. Subramaniam, Biochemistry 39 (2000) 2921-2930.

[79] U. Ermler, W. Grabarse, S. Shima, M. Goubeaud, R.K. Thauer, Curr. Opin. Struct, Biol. 8 (1998) 749-758.

[80] R.K. Thauer, Science 293 (2001) 1264-1265.

81] H. Dobbek, V. Svetlitchnyi, L. Gremer, R. Huber, O. Meyer, Science 293 (2001) $1281-1285$.

[82] J.M. Guisan, in: J.M. Guisan (Ed.), Methods in Biotechnology: Immobilization of Enzymes and Cells, second ed., Humana Press Inc, Totowa, NJ, 2006, pp. 1-13.

[83] J.K. Poppe, R. Fernandez-Lafuente, R.C. Rodrigues, M.A.Z. Ayub, Biotechnol. Adv. (2015) [in press]. 